Fall 12-1-2020

\title{
Development and Implementation of a Healthcare Volunteer Retention Program
}

\author{
Sandra Gomez \\ University of St. Augustine for Health Sciences, s.gomez1@usa.edu
}

DOI: https://doi.org/10.46409/sr.PMWI8139

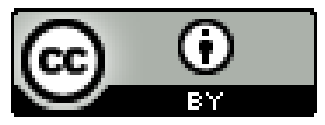

This work is licensed under a Creative Commons Attribution 4.0 License.

Follow this and additional works at: https://soar.usa.edu/scholprojects

Part of the Civic and Community Engagement Commons, Emergency and Disaster Management Commons, and the Public Health and Community Nursing Commons

\section{Recommended Citation}

Gomez, S. (2020). Development and Implementation of a Healthcare Volunteer Retention Program. [Doctoral project, University of St Augustine for Health Sciences]. SOAR @ USA: Student Scholarly Projects Collection. https://doi.org/10.46409/sr.PMWI8139

This Scholarly Project is brought to you for free and open access by the Student Research at SOAR @ USA. It has been accepted for inclusion in Student Scholarly Projects by an authorized administrator of SOAR @ USA. For more information, please contact soar@usa.edu, erobinson@usa.edu. 


\section{Development and Implementation of a Healthcare Volunteer Retention Program}

Sandra Hinojosa Gomez, MSN, RN

School of Nursing, University of St. Augustine for Health Sciences

This Manuscript Partially Fulfills the Requirements for the

Doctor of Nursing Practice Program and is Approved by:

Sarah M. I. Cartwright, DNP, MSN-PH, BAM, RN-BC, CAPA, FASPAN

Bruce K. Wilson, PhD, RN

December 1, 2020 


\section{University of St. Augustine for Health Sciences \\ DNP Scholarly Project \\ Signature Form}

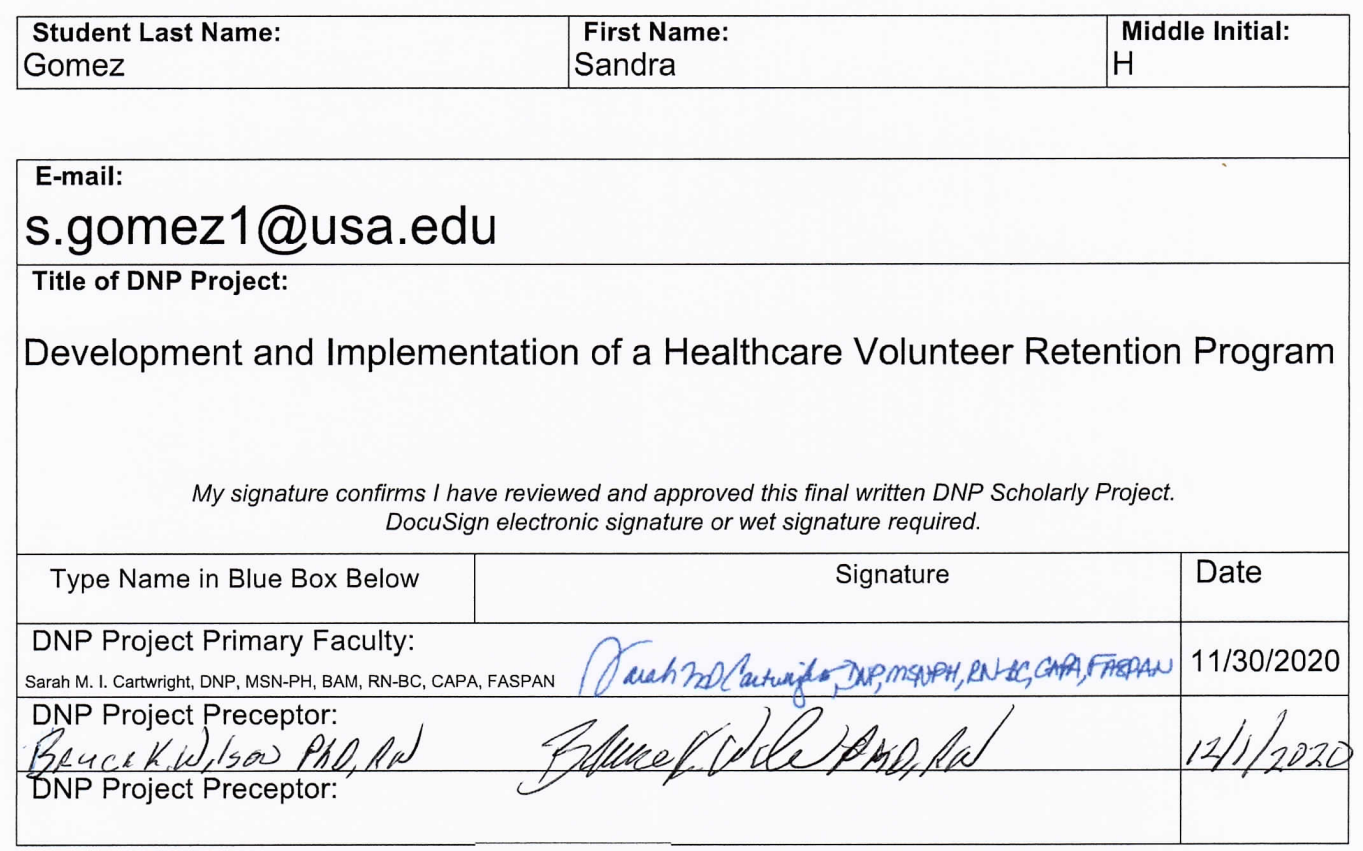




\begin{abstract}
Practice Problem: Healthcare volunteer responders are an asset during disasters, and their retention is necessary to meet rising demands. This project aimed to develop and implement an evidence-based practice change using a healthcare volunteer retention program and evaluate its influence on retention.
\end{abstract}

PICOT: The PICOT question that guided this evidence-based practice project was: In healthcare volunteers, how does the participation in a formal healthcare volunteer retention program influence healthcare volunteer retention rate, intent to stay, and volunteer satisfaction 12 weeks after Healthcare Volunteer Retention Program introduction?

Evidence: The evidence from the literature supported mentoring, education and training, and social support to retain healthcare volunteers.

Intervention: The Iowa Model Collaborative guided this project using the Plan, Do, Study, and Act framework to implement the Healthcare Volunteer Retention Program. Healthcare volunteer retention, education and training, and surveys before and after implementation were monitored to evaluate the retention program's influence.

Outcomes: The implementation resulted in a retention rate of $98 \%$, the intent to stay improved by $6 \%$, and $89 \%$ of the survey participants were satisfied with the retention program. Additionally, a paired-samples $t$-test conducted to compare the survey's results before and after implementation resulted in a $t$-value of 3.508 at alpha $=.05$, which supported the effectiveness of the retention program.

Conclusion: Local, regional, national, and worldwide opportunities exist to build capacity for healthcare volunteers. Disaster response readiness by healthcare volunteers requires mentoring, education and training, and social support to improve this workforce's retention. 


\section{Development and Implementation of a Healthcare Volunteer Retention Program}

Disasters such as extreme weather, major transportation accidents, and fire-related destruction have affected individuals worldwide (Keim et al., 2019). Disaster health responders offer relief and comfort to those who suffer from natural disasters and public health emergencies. According to Smith and Grove (2017), in two years, the American Red Cross (ARC) deployed 50,000 volunteers across the country to support victims of 125,000 domestic disasters. The provision of health and safety during disasters by healthcare volunteers (HVs) is in high demand, and volunteer retention strategies are crucial. Globally, numerous studies have documented the rising need for retention of HVs (Albuquerque et al., 2018; Chatio \& Akweongo, 2017; Haski et al., 2018; Mlotshwa et al., 2015; Moghaddam et al., 2018; Ngugi et al., 2018; Omoto \& Packard, 2016; Salmani et al., 2019; Sarti et al., 2017).

The purpose of this project was to develop and implement an evidence-based practice (EBP) change using a Healthcare Volunteer Retention Program (HVRP) to:

- influence retention of HVs,

- influence the HVs' intent to stay, and

- improve the satisfaction of the HVRP.

This paper includes discussions of the significance of this practice problem, the population, intervention, comparison, outcome, and timing (PICOT) of the PICOT question, the evidence-based practice framework and change theory, the evidence search strategy, search results and evaluation, a synthesis of the literature, and themes from the evidence. Furthermore, the paper outlines practice recommendations, project setting and overview, the project plan and method, results, impact, plans for dissemination, and a conclusion to this evidence-based practice change project. 


\section{Significance of the Practice Problem}

Disasters affect the overall health and well-being of many individuals. Humanitarian organizations rely on HVs to address public health needs during the direst of situations. However, we face a shortage of HVs across the world. The global healthcare worker shortage was 4.3 million in 2006, increased to 7.2 million in 2013, and is expected to rise to 12.9 million by 2035 (Afari-Asiedu et al., 2018). Therefore, innovative approaches to retain HVs are indispensable (Afari-Asiedu et al., 2018). Nonprofit organizations face competition for healthcare workers and retention of humanitarian volunteers (Smith \& Grove, 2017).

\section{Humanitarian Needs}

In 2018, a total of 850 natural catastrophic losses occurred around the world, which resulted in 15,000 fatalities and a monetary loss of $\$ 186,000$ million (Insurance Information Institute, 2020). As of March 2019, 355 fatalities resulted from 108 natural disaster events in the United States, with an estimated monetary loss of \$81.9 million (Insurance Information Institute, 2020).

Regionally, communities in Texas have suffered a variety of tropical storms, hurricanes, and flooding. In August 2017, Hurricane Harvey, a Category 4 storm, dropped 50 inches of rain, flooding more than 150,000 homes in one county, and causing at least 36 deaths (Trevizo, 2020). This storm required over $\$ 125$ billion in recovery costs (Trevizo, 2020). In September 2019, Tropical Storm Imelda caused flooding in at least 17,000 homes by dumping over 40 inches of rain and led to five people's deaths (Trevizo, 2020).

HVs are an essential resource for public health response (Smith \& Grove, 2017). Locally, the Rio Grande Valley in Texas has suffered substantial flooding, causing many people to seek shelter in the area (Gutierrez, 2019). A lack of HVs was evident during those floods, as 
individuals with multiple co-morbidities lost medications, durable medical equipment, and other basic supplies (Abbott, 2019).

\section{Volunteer Retention}

Low retention of humanitarian workers threatens the effectiveness of responses to disasters (Albuquerque et al., 2018). Albuquerque et al. (2018) described the need to strengthen retention strategies to improve humanitarian aid. In Africa, several studies have explored factors affecting retention of community-based health volunteers (CBHV), community health workers (CHW), and the sustainability of health activities (Afari-Asiedu et al., 2018; Chatio \& Akweongo, 2017; Mays et al., 2017; Mlotshwa et al., 2015; Ngugi et al., 2018; Vareilles et al., 2015). These researchers have suggested mentoring, education and training, and social support to encourage volunteer retention (Afari-Asiedu et al., 2018; Chatio \& Akweongo, 2017; Mays et al., 2017; Mlotshwa et al., 2015; Ngugi et al., 2018; Vareilles et al., 2015).

Beliefs, motivations, barriers, and psychological contracts in volunteerism have been investigated in the United States and Canada. These authors have recommended specific volunteer retention strategies to address the effectiveness and sustainability of world health needs in an unstable social and conflict-prone environment (Haski et al., 2018; Kim et al., 2019; McGeehan et al., 2017; Omoto \& Packard, 2016; Sarti et al., 2017; Smith \& Grove, 2017; Wilson \& Son, 2018).

Failure to address this humanitarian need for retention of HVs may have dismal consequences for victims of disasters (Salami et al., 2019; Smith \& Grove, 2017; Wilson \& Son, 2018). The retention of HVs poses a challenge for many volunteer organizations that compete with local healthcare systems and are already overwhelmed due to insufficient staffing during disasters and public health emergencies. 


\section{PICOT Question}

The PICOT question for this EBP project is: In healthcare volunteers, how does the participation in a formal healthcare volunteer retention program influence healthcare volunteer retention rate, intent to stay, and volunteer satisfaction 12 weeks after healthcare volunteer retention program introduction? Adults, 18 years of age and older with a healthcare skill, state license or certification, enrolled in the Disaster Health Service (DHS) activity from an interdisciplinary volunteer organization (IVO) served as the population for this EBP project (ARC, 2019a). The project manager (PM) was the Doctor of Nursing Practice (DNP) student who implemented this EBP change project.

The intervention was to develop, implement, and evaluate the HVRP to influence healthcare volunteer retention rate, intent to stay, and volunteer satisfaction at the IVO. According to Salmani et al. (2019), operational requirements are necessary for managing HVs. The HVRP is a guide used by a mentor and HVs with 30-, 60-, and 90-day reviews (see Appendix A) to navigate the onboarding and retention of HVs for mentoring, education and training, and social support to foster self-confidence and collaboration (Salmani et al., 2019). This HVRP utilizes the organization's existing volunteer handbook, standards and procedures, job training tools, and other resources (ARC, 2017; ARC, 2019b). The comparison question was whether differences and reasons exist for those who dropped out of the HVRP.

Permission was granted (see Appendix B) to use the Volunteer Functions Inventory (VFI) data collection tool (see Appendix C), which has been identified as the best-known survey for volunteer motivation, intent to stay, and volunteer satisfaction (Clary et al., 1998). The VFI was used to collect and compare data before and after implementing the HVRP (Alfes et al., 2017; 
Clary et al., 1998). Those who dropped out of the HVRP were analyzed separately. Data collection occurred throughout the EBP project to determine outcomes.

\section{EBP Framework and Change Theory}

Evidence-based practice is integrating "scientific knowledge with clinical expertise" to solve clinical issues and achieve the best outcomes in the delivery of patient care (Agency for Healthcare Research \& Quality [AHRQ], n.d.-b, para. 1). The EBP-driven Iowa Model Collaborative (IMC) guided this project to improve system changes and promote sustainability (IMC, 2017). The IMC has been successfully employed in multiple settings by novice to expert users to change health system outcomes positively (IMC, 2017). The Plan-Do-Study-Act (PDSA) framework is well-known, easy to follow, and reliable (AHRQ, 2018). The PDSA has proven effective in healthcare to test whether proposed changes lead to improvement and evaluate the improvement, costs, and other impacts (AHRQ, 2018).

A change model is most effective at guiding behavior and improving its implementation's success when paired with careful monitoring using validated tools to sustain change (Institute for Healthcare Improvement, 2020). The PM applied Kurt Lewin's (1947) three-stage model of change: unfreezing, moving, and refreezing in this EBP project with the HVRP at the IVO for behavior change.

During the unfreezing phase (Lewin, 1947), HVs resisted the change of the HVRP for the management of HVs. However, as Lewin (1947) predicted, belief in the need for the change eased passage into the next stage. The PM shared baseline data to retain healthcare volunteers, which improved transparency, commitment, and collaboration. Next, during the moving stage (Lewin, 1947), the leadership, staff, and HVs became familiar with and accepted the HVRP. Finally, during the refreezing phase (Lewin, 1947), the HVs and staff focused on the mission and 
embraced the HVRP. The implementation of the HVRP took place and became the new normal (Lewin, 1947). The mentors and HVs were aware of the expectations and sustained the process. The PM reported the final data to staff, HVs, and mentors. Lewin's Change Theory (1947) was the best fit for a healthcare innovation during a crisis and set the stage for positive change at the IVO.

\section{Evidence Search Strategy}

The PM conducted a literature review to find the evidence supporting this question: In HVs, how does the participation in a formal HVRP influence healthcare volunteer retention rate, intent to stay, and volunteer satisfaction 12 weeks after HVRP introduction?

The PM completed an electronic initial database search using the advanced search of the Cumulative Index to Nursing and Allied Health Literature Complete (CINAHL), PubMed, and MEDLINE. Employing Boolean Operators such as $A N D$ and $O R$, focused the search results. The headings and keywords for all searches were: volunteering OR volunteer OR volunteerism, AND healthcare professionals OR healthcare volunteers OR healthcare providers OR physician OR nurse OR doctor, AND retention. The search mode was find all my search words, and expanders included apply related words and apply equivalent subjects. The general limiters were English language only and publication date frame of 2015 to 2020. The results were: CINAHL 22 citations, PubMed 64 citations, and MEDLINE 24 citations. The PM found and combined one duplicate, leaving a total of 109 citations.

The titles and abstracts of the 109 articles were carefully reviewed for relevance according to the inclusion criteria: (a) volunteers; (b) healthcare volunteers; and (c) retention. The exclusion criteria employed by the PM eliminated children and teenage participants. The full 
text was retrieved for all articles that met the criteria, and then they were reviewed for final eligibility.

\section{Evidence Search Results and Evaluation}

A search of CINAHL resulted in 69 articles, PubMed 64 articles, and MEDLINE 10,000 articles, for 10,133 articles. Limiting the search to publications from 2015 to 2020 in the English language brought 109 articles. A review of the articles and titles was completed, which left 21 articles. The PM developed a PRISMA model (Moher et al., 2009) for the 21 articles included in the proposed EBP change project (see Figure 1).

The articles selected were identified as a global view of volunteer organizations struggling with retention of HVs. The evidence level and quality guide chosen to appraise the articles was the Johns Hopkins Nursing Evidence-Based Practice or JHNEBP (Dang \& Dearholt, 2017). The JHNEBP evidence levels ranged from Level I to V, and each article was assigned a quality grade (Dang \& Dearholt, 2017).

The evidence of the 21 articles ranged from Level I to II, and they were consistently A or B quality (see Appendix D). A theme-based intervention for the HVRP was supported. The PM studied the ARC website to establish an overview of the organization. The PM also reviewed the AHRQ and Institute for Healthcare Improvement websites to identify relevant quality tools.

\section{Synthesis of Literature Review}

A synthesis of the literature found evidence to support a critical need for retention of HVs. Results from the studies worldwide depicted the challenges organizations have competing for HVs in times of disasters and other humanitarian missions. Retention programs were suggested to support and mobilize volunteers for long-term commitments (Haski et al., 2018; Kim et al., 2019; McGeehan et al., 2017; Omoto \& Packard, 2016; Salmani et al., 2019; Sarti et 
al., 2017; Smith \& Grove, 2017; Wilson \& Son, 2018). Researchers around the world recommended exploring factors affecting retention of CBHVs and CHWs to support humanitarian aid (Afari-Asiedu et al., 2018; Albuquerque et al., 2018; Chatio \& Akweongo, 2017; Mays et al., 2017; Mlotshwa et al., 2015; Ngugi et al., 2018; Vareilles et al., 2015).

\section{Themes}

A careful review of the literature resulted in three major themes: mentoring, education and training, and social support. These themes were described in a context of operational functions related to the preparedness, response, and retention phases for long-term volunteer commitment (Albuquerque et al., 2018; Salmani et al., 2019; Wilson \& Son, 2018).

\section{Mentoring}

Findings in the literature showed the importance of social environments that eased and supported field missions by strengthening retention strategies (Albuquerque et al., 2018). Social support in the volunteer organization came in the form of a mentor who provided guidance and support through volunteering. An example was when a new volunteer reached out to a mentor who explained a process or a change that otherwise could have caused frustration and dissatisfaction. According to several studies in Africa, supportive supervision and feedback occurred during mentoring and led to community acceptance (Afari-Asiedu et al., 2018; Albuquerque et al., 2018; Chatio \& Akweongo, 2017; Mlotshwa et al., 2015; Ngilangwa \& Mgomella, 2018; Ngugi et al., 2018; Salmani et al., 2019). A positive experience with a training lead or mentor improved volunteer retention chances (Salmani et al., 2019).

In Africa, Canada, Sweden, and the United States, HVs were motivated by a mentor who reinforced the mission's goals and by the value of altruism to render aid to others in time of serious need during disasters (Afari-Asiedu et al., 2018; Albuquerque et al., 2018; Chatio \& 
Akweongo, 2017; Kim et al., 2019; Mays et al., 2017; McGeehan et al., 2017; Mlotshwa et al., 2015; Moghaddam et al., 2018; Ngilangwa \& Mgomella, 2018; Ngugi et al., 2018; Sarti et al., 2017; Smith \& Grove, 2017; Vareilles et al., 2015). According to O'Donohue et al. (2015), volunteers fulfilled the organizational obligation, sustained functional relationships, and enhanced performance and productivity by making a socio-emotional commitment to their supervisor or mentor.

\section{Education and Training}

Preparation for many CHWs came from individual experiences; however, education and training for role definition were important for the CHWs during onboarding, especially before a disaster response (Mlotshwa et al., 2015). While job inductions may be complex, a lack of clear process or guidance related to inadequate training can overwhelm the volunteer (Mlotshwa et al., 2015). New CHWs may struggle with role identity, which could pose a challenge during a real disaster (Mlotshwa et al., 2015). The literature showed CHWs wanted ongoing training and acquisition of knowledge through refresher courses in the community (Afari-Asiedu et al., 2018; Albuquerque et al., 2018; Chatio \& Akweongo, 2017; Mlotshwa et al., 2015; Ngilangwa \& Mgomella, 2018; Ngugi et al., 2018; Salmani et al., 2019). A strategic plan was suggested to create a structured retention program for engagement (Salmani et al., 2019).

In the VFI, the volunteer's career-building view was another motivator for volunteering (Alfes et al., 2017; Clary et al., 1998). Professional collaboration and knowledge sharing increased confidence and competence while volunteers integrated into the mission-ready culture of serving. Community recognition was also important for many volunteers (Afari-Asiedu et al., 2018; Albuquerque et al., 2018; Chatio \& Akweongo, 2017; Mlotshwa et al., 2015; Ngilangwa \& Mgomella, 2018; Ngugi et al., 2018; Salmani et al., 2019). Although the organization may offer 
a structured education plan, some HVs did not understand the engagement rules and dropped off the volunteer list due to failure to follow specific guidelines and requirements. Continuous engagement keeps HVs informed and active.

\section{Social Support}

A shortage of formal healthcare workers has left many rural communities neglected. The use of CBHVs to sustain healthcare activities has been effective, and the challenge to retain them was met by community support, incentives, and fulfilled logistical needs (Chatio \& Akweongo, 2017). A good example was the request that the CBHVs made for simple items (such as raincoats, torch lights, boots, and bicycles) as retention mechanisms (Chatio \& Akweongo, 2017). These individuals remained engaged and motivated by their desire to help the community while balancing their logistical needs with social support (Chatio \& Akweongo, 2017).

The healthcare volunteer, a socially integrated being who accepted volunteering through socialization and neighboring, benefitted from social support (Wilson \& Son, 2018).

Socialization and bonding within the organization affected the volunteer's intent to stay and their availability during disasters (Albuquerque et al., 2018). Communication, trust, and social bonding are integral to the volunteer relationship for retention, intent to stay, and volunteer satisfaction (Alfes et al., 2017; Clary et al., 1998; Salmani et al., 2019). Transformative volunteering is about enhancing motivation (Ortega Carpio et al., 2018). Communicating cultural and ethnic diversity is essential to social support (Meyer et al., 2016).

\section{Practice Recommendations}

After a careful review of the scientific evidence, the practice recommendation for this EBP project answered the PICOT question with the development and implementation of the HVRP (Salmani et al., 2019). The results from the evidence and grading are found in Appendix 
D. The themes (see Appendix E) strongly recommended mentoring, education and training, and social support for the retention of HVs. The evidence, according to JHNEBP, Level I and II articles with grades of $\mathrm{A}$ and $\mathrm{B}$, demonstrated similar themes related to mentoring, education and training, and social support (Albuquerque et al., 2018; Dang \& Dearholt, 2017; Salmani et al., 2019; Wilson \& Son, 2018). The development, implementation, and evaluation of the HVRP included the preparedness phase in which a mentor was assigned for education and training; a response phase for competency with continued mentor support; and a retention phase of social support. Compliance with the HVRP was monitored and reported to stakeholders. Ongoing briefings and education on the HVRP were also documented.

The evidence supported the HVRP necessary for the retention of HVs. The IVO's mission is the prevention and alleviation of suffering, which may be carried out with the mobilization and "power of volunteers" (ARC, 2020a, para. 1). The benefits of volunteering included a decreased risk for depression, a better sense of physical and mental health well-being, and improved social engagement and support (Nothwehr \& Rohlman, 2019). Furthermore, building trust, fostering a culture of collaboration, and building self-confidence during a steady state was important for retaining HVs (Salmani et al., 2019). Salmani et al. (2019) stressed the importance of having plans at the operational level and supported requirements in the preparedness phase to include education and training; mentoring in the response phase for supportive supervision; and a need to address retention by implementing plans for follow-up of physical and mental health after a mission. Volunteers work alongside paid employees; therefore, management must have a keen understanding of keeping volunteers engaged and supported (ARC, 2019a). The leadership approved the recommendation to implement the HVRP at this IVO. 


\section{Project Setting}

The project setting for this EBP project was an IVO that covered HVs from the Southeast and Deep East Texas, Greater Houston, Coastal Bend, and South Texas (ARC, 2020c). The regional headquarters office is in Houston, Texas. HVs accessed their chapter through virtual modalities such as the Microsoft (MS) Teams website application and Volunteer Connection (VC). The region is proud to serve the community with various missions such as Disaster Services, Service to Armed Forces, International Services, and Preparedness Health, Safety, Development, and Volunteer Opportunities (ARC, 2020c). The IVO has board officers and elected board members with regional and chapter leaders in collaboration with local and corporate partners (ARC, 2020c).

\section{Clients}

A typical client at the IVO could have come from any age, ethnic, cultural, and financial background. The client may have been healthy or had multiple co-morbidities with varying types and degrees of disabilities. Some victims of disasters suffered the loss of durable medical equipment and medications, while others struggled with the disaster situation itself and required mental health referrals (Abbott, 2019).

\section{Organizational Structure, Culture, and Need}

The IVO professed to have a strong employee and volunteer engagement (ARC, 2020c). Readiness for change was accepted by leadership. The organizational structure supported a strong workforce of human resources, data infrastructure, management, and logistic support. The organization's reputation as a community resource is one of its' demonstrated strengths (Abbott, 2019; ARC, 2020c). The IVO leadership follows a territorial or chapter, regional, divisional, and national structure (ARC, 2020b). 
The IVO offered virtual and in-person education and training to the staff, volunteers, and the community. However, in-person education was restricted during the COVID-19 pandemic of 2020. The organization valued cultural diversity by proving its commitment to openness and inclusion for all staff, volunteers, and clients (ARC, 2020a). The organization also supported international missions to Mexico and other countries as an international resource. Virtual deployments were available for individuals who had the skill sets to volunteer in specific areas such as mental health, spiritual care, and some health services.

According to a conducted needs assessment and gap analysis, the retention of HVs was a problem at the IVO. A completed Fishbone Diagram showed a lack of structured process for onboarding, mentoring, and offering growth opportunities for new HVs (Association of Quality, 2019). These results determined that a lack of standardization was evident for mentoring, education and training, and social support to retain HVs in this organization and identified a need for an EBP project to be planned, implemented, and evaluated to create positive change.

\section{Organizational Support, Stakeholders, and Sustainability}

The IVO leadership expressed a need to improve the retention of HVs. Additionally, a healthcare chapter leader was the preceptor for the PM and supported the DNP scholarly project. The IVOs leadership key stakeholders were the Regional Disaster Health Service Lead (RDHSL) and chapter leaders. The RDHSL had authority and supervision for the compliance of healthcare volunteer mentors to implement the HVRP. Briefings and education were afforded with the support of leadership. Other stakeholders included chapter leaders and supervisors from other departments, such as volunteer engagement.

Support was evident throughout the collaborative engagement of HVs from the IVO. Client satisfaction was at stake due to the scarce resource of HVs to ensure the safety and 
wellness of clients displaced by a disaster. The facility leadership supported the sustainability of the HVRP for the management of HVs. The chapter leaders were actively involved with the RDHSL and PM for the implementation of the HVRP. The mentor's compliance with the implemented HVRP was imperative to its success. The HVRP implementation was monitored and documented using the HVRP form (see Appendix A). This project was also sustained by continuously educating new and existing HVs about the HVRP process (Smith \& Grove, 2017).

\section{Interprofessional Collaboration}

The interprofessional collaboration within the IVO was needed for the sustainability of this EBP project plan. The RDHSL had oversight of HVs and mentors. The RDHSL and PM met with the mentors monthly to ensure the mentors fulfilled their HVRP implementation responsibility.

\section{The Strengths, Weakness, Opportunities, and Threats Analysis}

A strengths, weakness, opportunities, and threats analysis, referred to as SWOT, was conducted to identify issues and establish strategies to meet the organizational need for a project plan (AHRQ, n.d.-a). The facility's strengths included its mission, vision, core values, and pillars with a guiding philosophy. Another strength was their history, which stretched back to 1881 when Clara Barton founded the ARC (ARC, 2020b). Barton provided aid to soldiers during the Civil War in the early years of 1881, and the IVO has since been respected internationally for responding to disasters (ARC, 2020b). The IVO has a strong and esteemed public image in the community. Other strengths included technology, resources, and leadership support (see Appendix F).

The internal weaknesses were the reduced healthcare volunteer participation and a lack of structured mentoring, education, and training. Opportunities existed for collaboration with local 
healthcare organizations and colleges during disaster relief efforts. Finally, the threats to this organization included healthcare volunteer resources being exhausted due to long-standing disaster relief missions and multiple ongoing disasters (Abbott, 2019).

\section{Project Overview}

The purpose of this EBP project was to compare how the implementation of the HVRP that included mentoring, education and training, and social support influenced healthcare volunteer retention rate, intent to stay, and volunteer satisfaction 12 weeks after HVRP introduction.

\section{The Project Vision and Mission}

The vision and mission conveyed the purpose of the EBP project, objectives, and goals. Together, the vision and mission guided the participants' adherence to the intervention's support and sustainment. This EBP project's vision was client access to the delivery of care by HVs during a disaster response. This EBP project's mission was to successfully implement the HVRP and influence the retention rate of HVs, their intent to stay, and overall volunteer satisfaction. This vision and mission were parallel to those of the IVO (ARC, 2020a).

\section{Objectives, Risks, and Unintended Consequences}

The objectives, short-term goals, and long-term goals guided this EBP project. The shortterm goals of this EBP project included: 1) to implement the HVRP by July 2020; 2) to influence the healthcare volunteer retention rate; 3 ) to improve the intent to stay by $5 \%$ in over 12 weeks from HVRP introduction; and 4) to improve healthcare volunteer satisfaction by 5\% in over 12 weeks. A long-term goal is to disseminate the planned intervention of the HVRP to the national level of the IVO within the following year. Another long-term objective is to offer this HVRP to other volunteer organizations through the next three years' annual conventions. 
The PM used a risk matrix tool to find risks. The strategy was to address the risks with the highest score. The interprofessional team approach was used to address risks and unintended consequences and proved helpful in this assessment and for this project's success. Training of the mentors and HVs was essential to begin the behavior change. A well-defined plan was considered, prepared, and implemented to address operational issues such as a shortage of mentors, resistance to change, internet interruption or failure, and other associated technical issues.

Limitations included volunteer shortages related to unavailable HVs affected by the COVID-19 pandemic of 2020 and the environmental stressors. Supervisors worked diligently with each other to ensure that the disaster response was uninterrupted. Interprofessional collaboration occurred at all stages of the HVRP intervention. Clear and concise communication was focused on the mission. The chapter leaders helped with the change process and addressed any resistance issues due to volunteer shortages.

\section{Project Plan}

The IMC guided the EBP project plan with the PDSA process (AHRQ, 2018; IMC, 2017). The IMC approach is systematic and links EBP practice changes within a system (IMC, 2017). The PDSA model (AHRQ, 2018) linked the elements of using the HVRP for the management of HVs. The description of the implementation plan, schedule, and budget are necessary to summarize the details of the EBP project plan or method used.

\section{Lewin's Change Management Model}

Kurt Lewin's change model was a guide for this EBP project, and it identified barriers to change using the three-stages: unfreezing, moving, and refreezing (Lewin, 1947). The expected change was the acceptance of the HVRP implementation by the staff and HVs of the IVO. 


\section{Unfreezing Stage}

During the unfreezing phase (Lewin, 1947), the IVO's HVs were in a state of awareness, recognized the shortage of volunteers, and understood the urgency of a retention program. The PM and IVO key stakeholders organized an interprofessional team that included HVs and chapter leaders from the health services. Early communication was important to discuss challenges, barriers, and strategies to define the project's direction.

\section{Moving Stage}

During the moving stage (Lewin, 1947), the project's implementation occurred with the support of IVOs leadership. The RDHSL and PM monitored the schedule, education, and volunteer response, which was central to the project's success. Clear communication of the implementation plan had to occur, and an opportunity for questions and concerns was granted to ensure compliance and sustainability.

\section{Refreezing Stage}

The refreezing stage (Lewin, 1947) allowed a time for stability and reflection on the implementation. A continuous effort was made to support the goals of influencing retention rates, intent to stay, and overall healthcare volunteer satisfaction. Education and briefings continued to benefit the HVs. Once the implementation was completed, the process was evaluated, summarized, and reported to the stakeholders to describe the challenges, successes, and goals achieved.

\section{The Intervention}

The IVO leadership identified a threat in retaining HVs and communicated the issue while assessing the organizational needs. The IMC served as a guide and framework with the PDSA process to test a change at the IVO with the implementation of the HVRP for this EBP 
project (AHRQ, 2018; IMC, 2017). The intervention was the HVRP. The observed outcomes were the retention rate, intent to stay, and overall volunteer satisfaction post-implementation. These outcomes were compared using the VFI post-implementation survey scores compared to the VFI pre-implementation survey scores.

The statistical analysis outlined the outcomes of the VFI pre- and post-implementation surveys. Outcomes and data were observed and collected before the implementation to analyze the effectiveness of the intervention. VFI pre- and post-implementation surveys were analyzed, and the results were reported to the stakeholders. The barrier to change was a lack of knowledge. The PM was available as a resource and provided education and awareness. The interprofessional collaboration was evident throughout the IVO. The PM displayed patience and respect during this process to affect the change process.

During the Plan step of the PDSA model (AHRQ, 2018), the PM and RDHSL coordinated the interprofessional team and EBP project champions to orchestrate the implementation plan. The RDHSL had the authority to make decisions related to health services and was a resource for identifying barriers and facilitators to ensure the EBP project progressed as planned. The RDHSL was involved in the educational plan and training for the mentors. The RDHSL also assisted the PM in collecting and analyzing the data. Formative assessments were also used to ensure continuous improvements to the EBP project.

Key players had to agree to their assigned role during the planning stage for this EBP project to be successful. The interprofessional meeting took place with the stakeholders. The RDHSL and PM collected baseline data of new and existing HVs at the IVO and reported them to the stakeholders. Next, the PM met with the RDHSL to review the HVRP for implementation. 
During the Do step (AHRQ, 2018), the PM sent a communication by email to the HVs to introduce the HVRP. The PM, acting as a resource, scheduled an appointment with the RDHSL to provide education to the staff and HVs about the HVRP at the following monthly meeting. Next, the PM distributed the VFI pre-implementation survey to the HVs. Finally, in collaboration with RDHSL, the PM educated the mentors on using the HVRP; then, the implementation began with new and existing HVs (Alfes et al., 2017; Clary et al., 1998; Kim et al., 2019). The HVRP was used as a formative evaluation.

Then, during the Study step of the PDSA (AHRQ, 2018), the data collection occurred and guided the evaluation. The PM collected, reviewed the results, analyzed, and reported findings from the VFI pre-implementation surveys to the stakeholders. The PM administered the VFI post-implementation survey to the HVs at the end of the 12 weeks from the HVRP introduction; then, reviewed the survey results, analysis, evaluation of the implementation, and reported to the stakeholders (Alfes et al., 2017; Clary et al., 1998; Kim et al., 2019). A bar chart was used to display the results shared with the stakeholders. The PM reported cost issues to the stakeholders twice during this EBP project to keep the stakeholders informed. Finally, the PM collected the outcome data; with assistance from a statistician, the PM compared the baseline, VFI pre- and post-implementation data; evaluated retention, intent to stay, and satisfaction; then reported those results to the stakeholders.

Finally, based on the VFI results, a collaboration occurred during the Act step of the PDSA (AHRQ, 2018), and modifications were made to improve areas of the HVRP. The results were analyzed to determine the HVRP met the objective to influence the retention rate for HVs, the intent to stay, and volunteer satisfaction. The results supported the sustainability of the 
HVRP, and preparations began to disseminate this EBP project locally at the IVO, regionally, and then nationally. The final summative evaluations were explained to the stakeholders.

\section{Barriers and Facilitators}

Barriers and facilitators are part of EBP projects. One barrier in this EBP project was related to volunteer shortages caused by a demand for formal healthcare workers during the pandemic of 2020. Another barrier was the lack of knowledge in the latest technology and the adopted systems because of the restrictions related to social distancing and the environment. HVs had trouble navigating the electronic system. Leadership support is the best type of facilitator for this organization. Leadership monitored efficiency and compliance of the intervention. The behavior change was led by the RDHSL and followed by the HVs.

\section{Project Schedule}

The EBP project proposal was first submitted for review by the Evidence-Based Practice Project Review Council (EPRC) from the University of St. Augustine for Health Sciences (USAHS) before implementation. The purpose of the EPRC was to review the DNP scholarly EBP project proposal to ensure a reflection of the knowledge will be used and transferred to other programs within the organization. Once the EPRC approval was granted, the EBP project proposal was submitted to the IVO leadership for review and approval.

After obtaining approval from the USAHS and the IVO, the PM met with the IVOs leadership team to share the approval and discuss the EBP project implementation dates and projected budget. Next, the PM collected the baseline data of new and existing HVs at the IVO. Then, the PM reviewed the HVRP with the RDHSL, sent an email with written notification of EBP project implementation to the HVs, and RDHSL introduced the HVRP at the staff meeting. 
The PM re-created a pre-implementation survey using the VFI in the MS Forms application (Clary et al., 1998). The VFI is a validated tool with high reliability (Chacon et al., 2017). The PM administered the VFI pre-implementation survey to the HVs. The HVs received an email with the link accessing the survey for completion (see Appendix C). The volunteers' IVO assigned identification number was used to match the VFI pre-and post-implementation surveys for comparison. The surveys were voluntary, and the potential for harm was minimal. The results of the surveys were analyzed and reported to the stakeholders. The PM was a resource and provided education to the mentors and HVs. Once the training was complete, the PM began the EBP project intervention. In collaboration with the RDHSL, the PM collected data of new HVs during the implementation and acted as the point of contact for the workgroup while coordinating any changes and requests for changes.

The PM administered the VFI post-implementation survey 12 weeks from the HVRP introduction and collected the results from the HVs by extracting the information using an MS Excel worksheet for input into the IBM Statistical Package for Social Sciences (SPSS) version 23. The PM removed any personally identifiable information from the Excel worksheet results and emailed it to the statistician to analyze the survey outcome data. The data were analyzed using SPSS 23. The cost incurred was reported to the stakeholders twice during this EBP project. Once all the data had been analyzed and documented, the PM prepared and offered a presentation to the stakeholders. See Appendix G for the EBP Project Schedule.

\section{Budget and Resources}

The resources required for this EBP project have indirect costs. HVs are not paid; therefore, there was no direct cost. The budget was presented to the leadership of the organization for review. Resources used included virtual modalities accessed by HVs at their 
cost. Educational material was electronic, and printing was not needed unless each volunteer chose to print. A $\$ 5$ gift card for survey participation was issued to each volunteer per survey completed and totaled $\$ 145$. Other expenses included cards and stamps for mailing the gift cards. Total expenses were $\$ 168$ (see Table 1).

\section{Project Management Role and Leadership Skills}

The PM had a significant role in this high impact EBP project and had to demonstrate to be flexible, adaptable, and a good communicator, which are leadership skills crucial to lead and guide the team within the budgetary goals, the scheduled time frames, and understand the scope for implementation to reach the objectives. The PM's responsibility was to encourage and motivate the interprofessional team to move the EBP project into an atmosphere conducive to teamwork.

\section{Results}

Data collection and analysis were vital to the success of this EBP change project. The IVO had 91 team members who participated in implementing a formal HVRP in June 2020 after approval from the EPRC of the USAHS and IVO that same week. This section includes data collected along with an analysis and discussion of the results.

The PM collected baseline data of new and existing HVs at the IVO DHS. The PM and statistician used the IBM SPSS 23 to identify the EBP project outcomes' statistical significance with a paired $t$-test that compared VFI pre- and post-implementation survey results. The independent variable was the introduction of the HVRP. Dependent variables were the retention rate, intent to stay, and volunteer satisfaction.

The sustainability measure was the percent of HVs enrolled in the HVRP (see Appendix H). Figure 2 shows the participants' frequency and percentage distribution by chapter group and 
the total number of participants. Green bars indicate the frequency, and blue bars indicate the percentage. There were 91 participants. The IVO headquarters is in Houston, Texas, which accounted for $82 \%$ of the participants.

\section{Figure 2}

Frequency and Percentage Distribution of Participants by Chapter Group

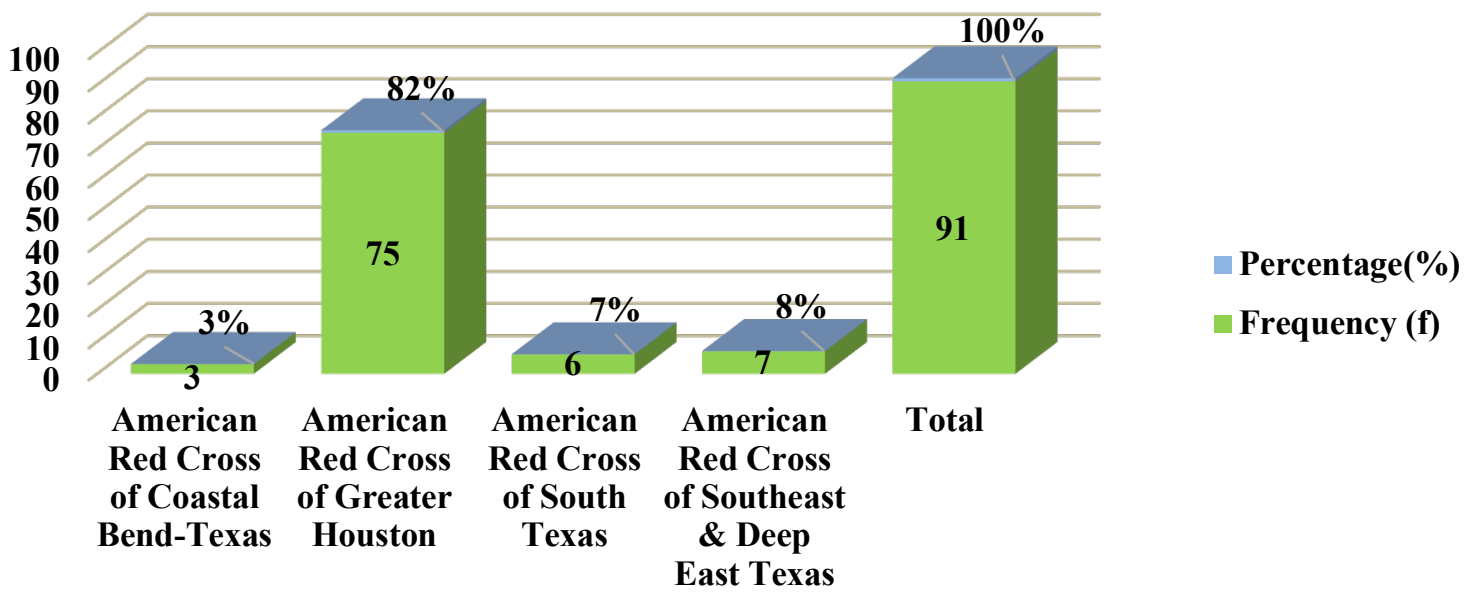

Years of service is an influential factor in the retention of HVs. Figure 3 contains the frequency and percentage distribution of participants by years of service group. Green bars signify frequency, and blue bars signify percentage. There was a total of 91 participants. The calculated mean age was 3.32 , and the standard deviation was 8.15 . Two participants who dropped off the volunteer list were within the 5 years and below service group. The reasons for dropping off the volunteer list included: relocation to another region, going back to college, and secular work demands. 


\section{Figure 3}

Frequency and Percentage Distribution of Participants by Years of Service Group

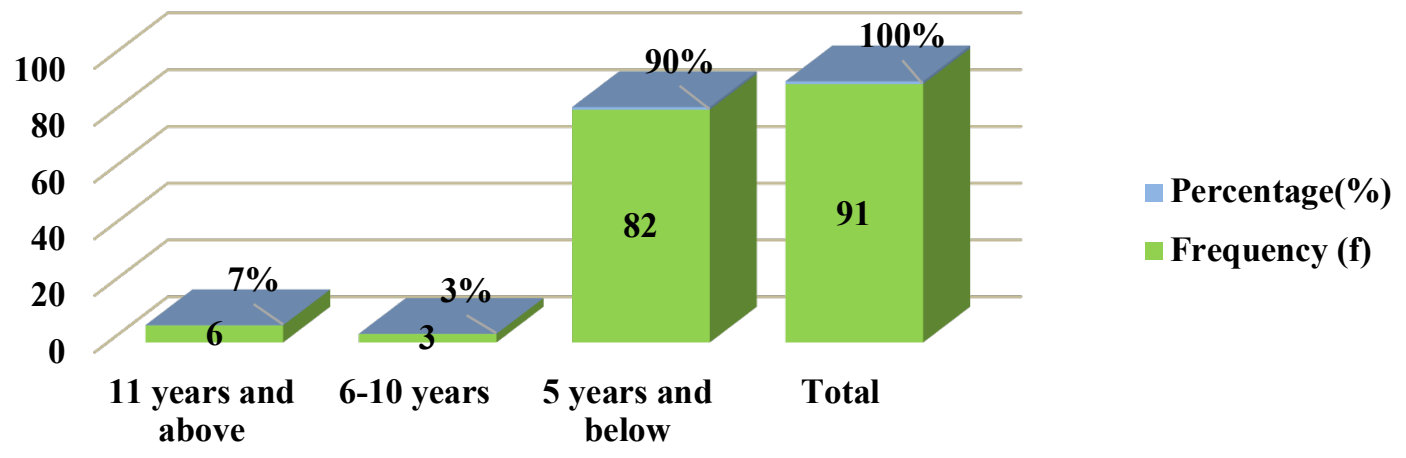

Another strategy was to analyze participants by county. Figure 4 contains the frequency and percentage distribution of participants by county group and the total number of participants. Green bars signify frequency, and blue bars signify percentage. There was a total of 91 participants.

\section{Figure 4}

Frequency and Percentage Distribution of Participants by County Group

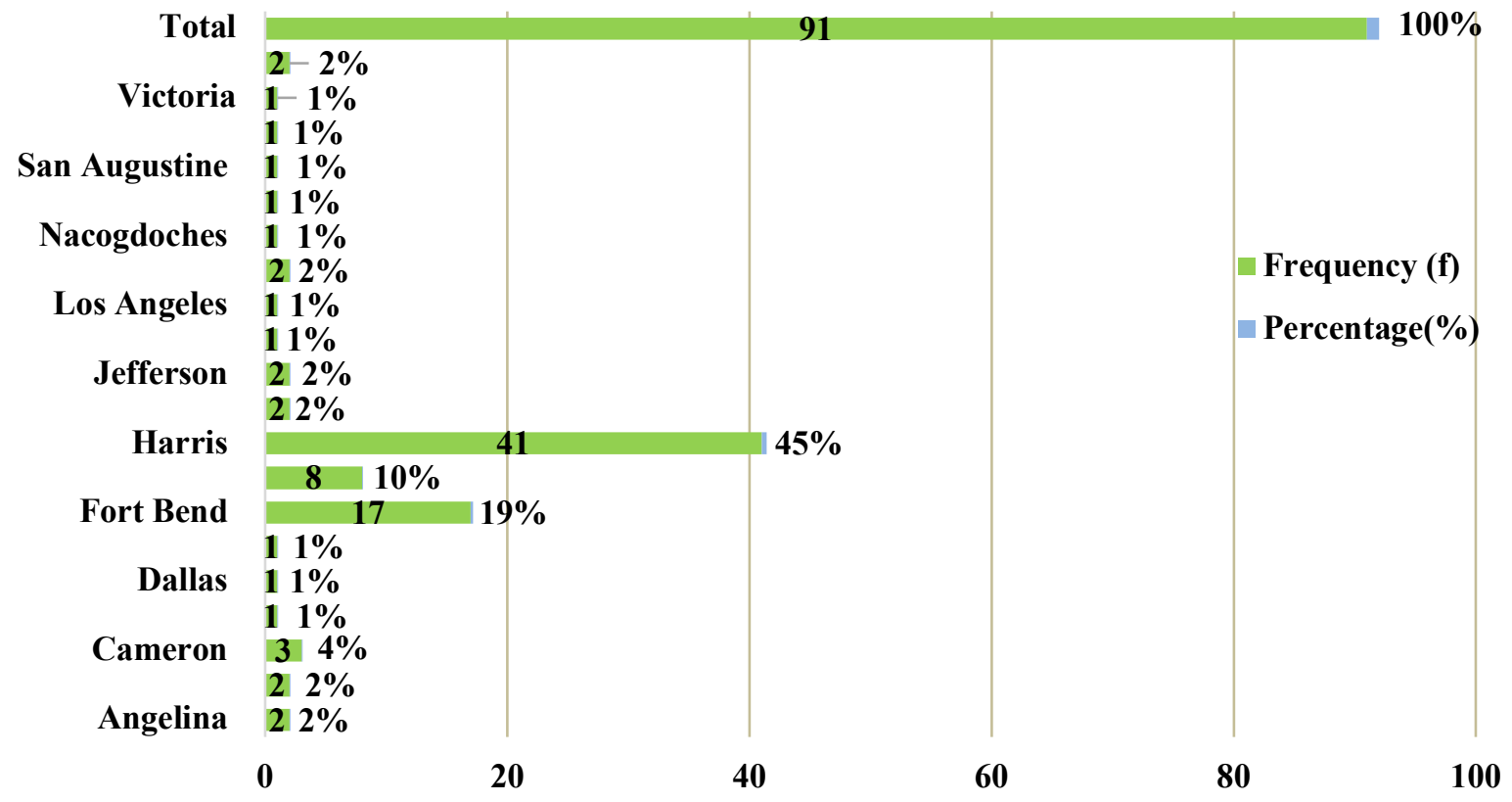


During the Do step of the PDSA (AHRQ, 2018), the RDHSL formally invited the HVs to a DHS Orientation. The DHS Orientation was added to the DHS Training Calendar for registration. HVs had access to register for classes in VC. The process measure was the percent of trained mentors (see Appendix H). In this EBP project, 100\% of the mentors were trained.

The VC was used to send a group email with the survey link to participants. Participants were asked to enter their IVO assigned number or name to match the VFI pre- and postimplementation survey results. They were also reminded that the facility leadership approved the survey; it was voluntary, and that their name and email address would not be shared. The potential for harm was minimal and included personal time (8-10 minutes) to complete each survey.

The VFI pre-implementation survey return rate was 18 , or $20 \%(n=91)$. The VFI postimplementation survey return rate was 18 , or $20 \%(n=91)$. Thirteen participants or $14 \%(n=91)$ completed both VFI pre- and post-implementation surveys. The PM identified two issues that caused poor survey participation. First, since the survey link was not active within the email, participants had to copy and paste it into a web browser. Secondly, the email with the survey link was going into the participant's "Junk" folder and was missed as reported by the HVs during a staff meeting. The RDHSL sent a second email with a survey link to the participants. The PM collected and extracted results of the VFI pre-implementation surveys using an MS Excel worksheet. Results were then analyzed and reported to the stakeholders.

The PM and RDHSL collected and stored the data using password protection to maintain survey integrity. The PM replaced the HVs names with the IVO assigned numbers and matched the VFI pre- and post-implementation survey results. The VFI pre- and post-implementation surveys that did not match each other were given a consecutive identifying number for analysis 
that was not paired. HVs personally identifiable information was removed before the Excel worksheet analysis, and the final document was copied into a new Excel worksheet identifying each HV with a number. Participants’ rights were protected.

During the Study step of PDSA (AHRQ, 2018), the PM received reports of a lack of participant interest when the mentors texted, called, and emailed them to engage in volunteer activities and register for the DHS Orientation. Participants who did not attend the DHS Orientation were invited several times. Figure 5 shows the frequency and percentage distribution of their engagement in the last 180 days. The total number of participants was also included in the table. Green bars indicate the frequency, and blue bars indicate the percentage. Figure 5 shows $74(81 \%)$ participants were Yes for their engagement in the last 180 days, and $17(19 \%)$ participants were No for the lack of engagement in the past 180 days. There were 91 participants.

In comparison, Figure 6 shows the participants' frequency and percentage distribution of their engagement in the last 30 days. The total number of participants was also included in the table. Green bars indicate the frequency, and blue bars indicate the percentage. As shown in Figure 6, 57 (63\%) participants were Yes for their engagement in the past 30 days, and 34 (37\%) participants were No due to lack of their engagement in the 30 days. There were 91 participants. The percentage of those who were not engaged in the last 30 days was twice as almost high as the comparative figure within the last 180 days (Figure 5). A busy storm season and the COVID19 pandemic of 2020 negatively impacted the HV participants' engagement, as reported at the DHS staff meetings. The RDHSL reminded the HVs during the staff meetings to enter volunteer hours in the $\mathrm{VC}$ and recommended that this reminder become part of the monthly checks to prevent HVs from dropping off the volunteer list due to lack of recorded hours. 


\section{Figure 5}

Frequency and Percentage Distribution of Participants by Last 180 Days Engagement Group

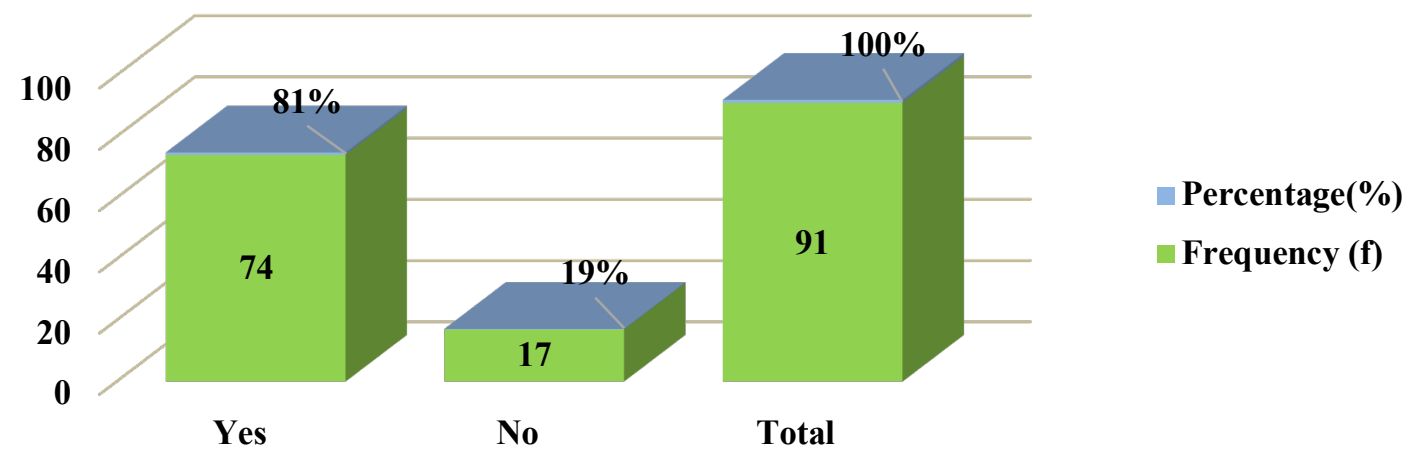

\section{Figure 6}

Frequency and Percentage Distribution of Participants by Last 30 Days Engagement Group

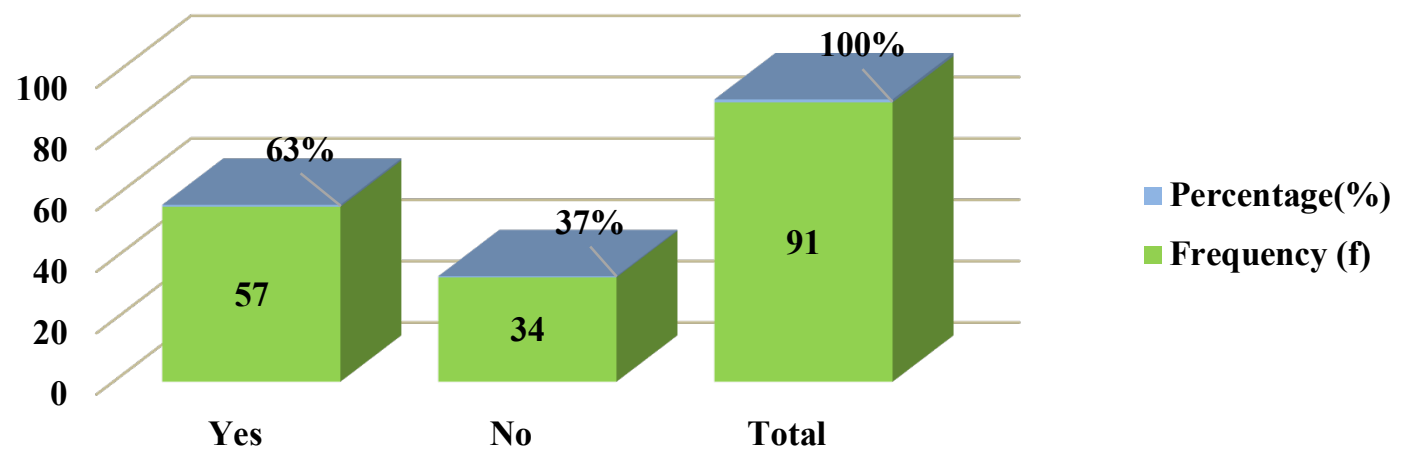

During the Act step of PDSA (AHRQ, 2018), the PM met with stakeholders, and a discussion ensued to revise the HVRP. The revised HVRP shown in Appendix A was shared with stakeholders. The HV and mentor have specific tasks related to each phase of the HVRP that may be individualized for each HV. Consistent communication is important to the engagement and overall retention of the HVs.

The outcome measure (explained in Appendix H) may be viewed in Figure 7, which shows the survey participants' frequency and percentage distribution of intent to stay before 
implementing the HVRP. The total number of survey participants was also included in the table. Green bars indicate the frequency, and blue bars indicate the percentage.

\section{Figure 7}

Frequency and Percentage Distribution of Participant's Intent to Stay Before the HVRP

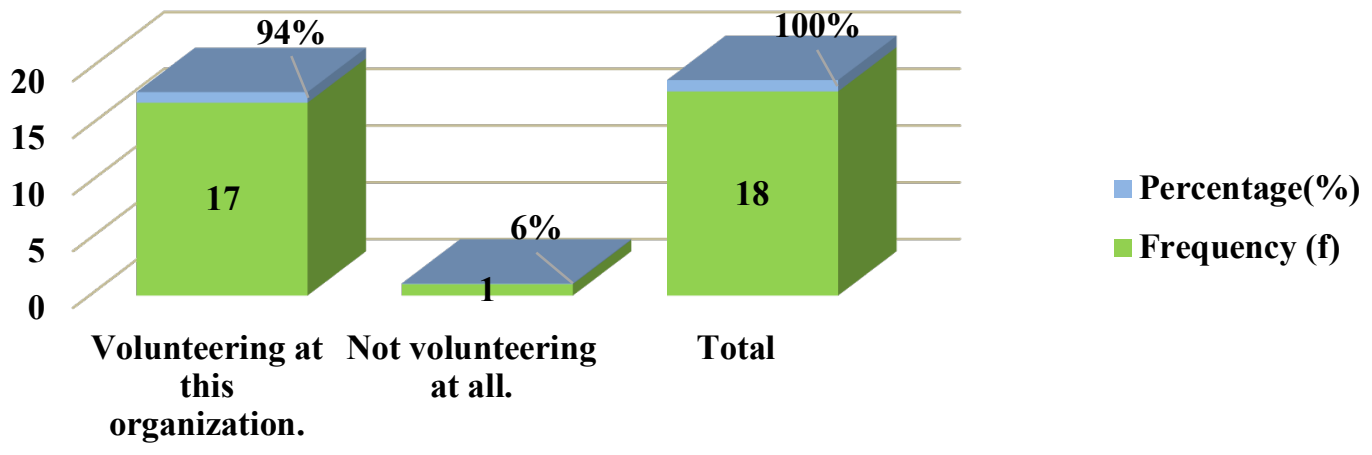

Figure 8 shows the survey participants' frequency and percentage distribution intent to stay after implementing the HVRP. The total number of survey participants was also included in the table. Green bars indicate the frequency, and blue bars indicate the percentage. As shown in Figure $8,18(100 \%)$ survey participants answered that they would be volunteering at this organization. There was a $6 \%$ improvement in the intent to stay by the HVs, which exceeded the outcome measure goal by $1 \%$ (see Appendix $\mathrm{H}$ ). There were 18 survey participants.

\section{Figure 8}

Frequency and Percentage Distribution of Participant's Intent to Stay After the HVRP

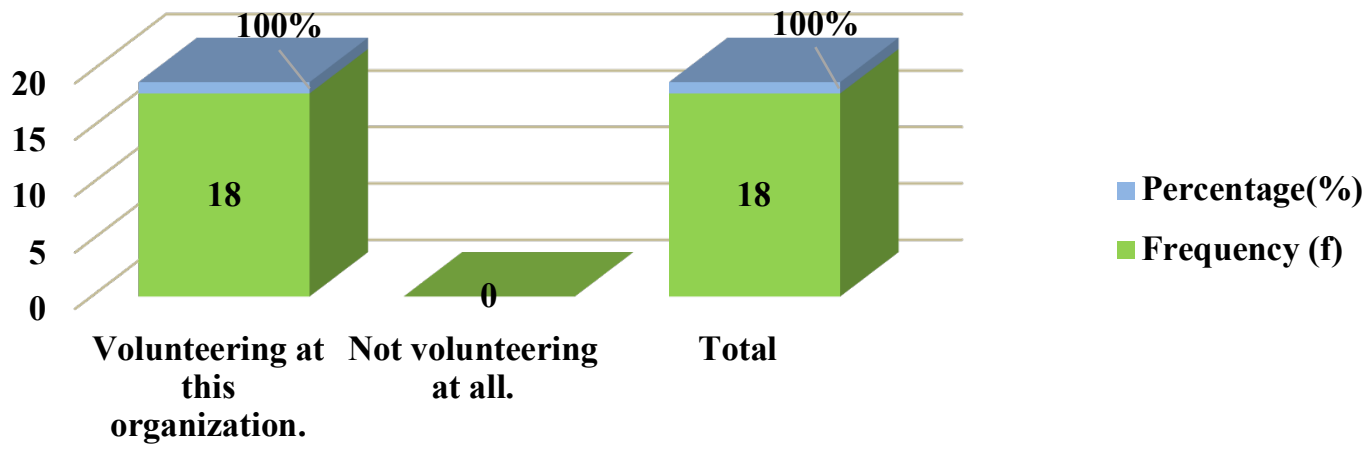


The balancing measure was the percent of HVs satisfied with the HVRP. Figure 9 shows the participants' frequency and percentage distribution by HVs satisfaction in the HVRP. The total number of participants was also included in the table. Green bars indicate the frequency, and blue bars indicate the percentage. Overall, the 16 survey participants, based on the data, were satisfied with the HVRP.

\section{Figure 9}

Frequency and Percentage Distribution of Participant's Satisfaction in the HVRP

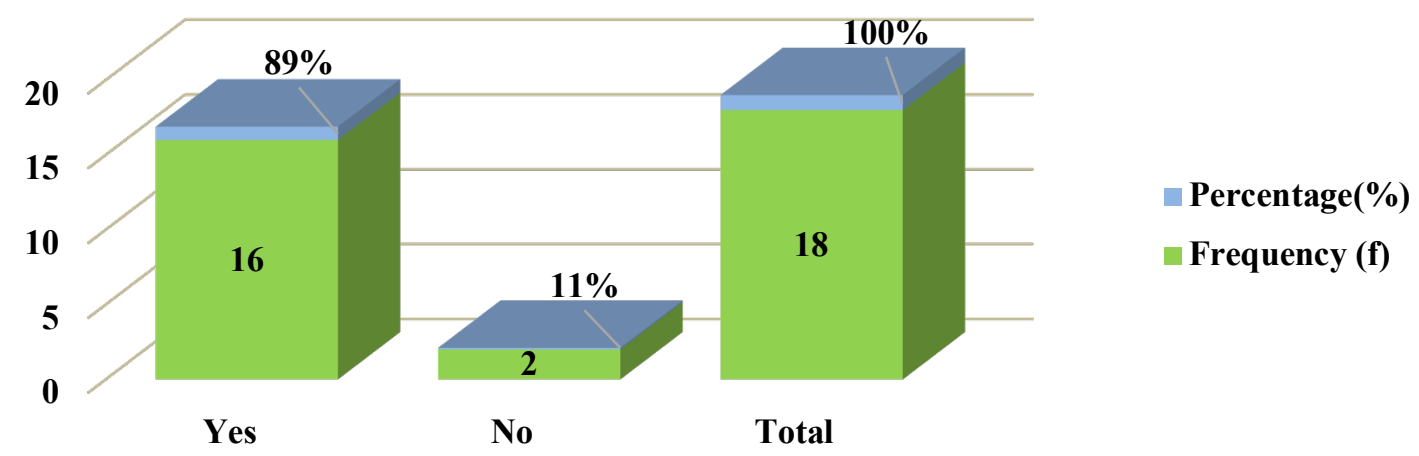

Outcome measures included a retention rate per 100 for HVs at the IVO. Figure 10 shows the frequency distribution by retention rate. Two volunteers dropped off the list. The retention rate was $98 \%$. Therefore, more than $50 \%$ of the HVs were influenced by HVRP.

\section{Figure 10}

Frequency of Retention Rate

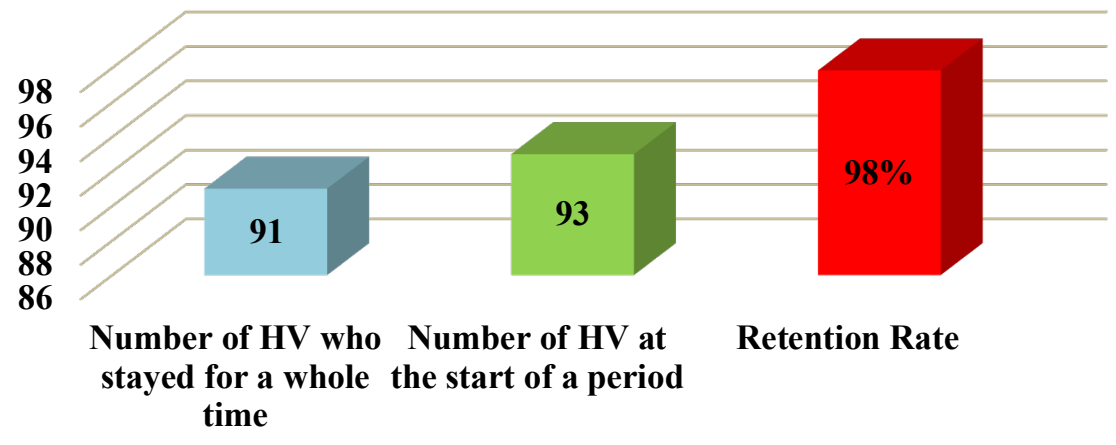


As shown in Table 2, a paired-samples $t$-test compared the results of the VFI pre- and post-implementation surveys. The VFI pre-implementation survey had a calculated mean of 142.91 and a standard deviation of 37.98. The VFI post-implementation survey had a calculated mean of 218.38 and a standard deviation of 65.54 . The resulting $t$-value of 3.508 at alpha $=.05$ showed a statistically significant difference, suggesting the HVRP implementation was effective for HVs.

Table 2

VFI Pre- and Post- HVRP Implementation Paired Sample Statistics

\begin{tabular}{ccccccc}
\hline Variables & $N$ & Mean & $S D$ & $D f$ & $t$-value & $p$-value \\
\hline $\begin{array}{c}\text { Pre- } \\
\text { implementation } \\
\begin{array}{c}\text { Post- } \\
\text { implementation }\end{array}\end{array}$ & 13 & 142.92 & 37.98 & & & \\
\hline
\end{tabular}

Significant at the 0.05 level (2-tailed).

\section{Impact}

The primary outcome addressed by this EBP project was the development, implementation, and evaluation of a retention program with the Preparedness, Response, and Retention Phases. Three themes emerged from the evidence: mentoring, education and training, and social support. These themes influenced the retention of HVs, their intent to stay, and satisfaction with the HVRP (Albuquerque et al., 2018; Salmani et al., 2019; Wilson \& Son, 2018). Social support in the form of a mentor for guidance within the IVO allows for the acquisition of knowledge through ongoing training and sharing of volunteer experiences with supportive supervision, feedback, and engagement through meetings, award ceremonies, networking for socialization and bonding that affects their retention, intent to stay, and 
satisfaction (Afari-Asiedu et al., 2018; Albuquerque et al., 2018; Chatio \& Akweongo, 2017;

Mlotshwa et al., 2015; Ngilangwa \& Mgomella, 2018; Ngugi et al., 2018; Salmani et al., 2019).

The EBP project improved practice for the IVOs DHS group by implementing a process in which HVs are assigned and meet with their mentor during the DHS Orientation. The practice change includes mentors who are trained in the HVRP. The HVs and leadership easily accepted the HVRP due to the cost-effectiveness and ease of implementation. Although only two participants volunteered to be mentors for this project period, a total of seven participants volunteered to be mentors at a future time, which gave a sense of a lasting effect by the HVRP.

Several issues were identified with the recruitment of mentors. HVs reported that they were busy with disaster relief operations during the hectic hurricane season. MS Teams application was the latest technology software that challenged most participants. The COVID-19 pandemic of 2020 gave way to more training requirements. Nevertheless, the HVs were dedicated to the mission and vision of the IVO. The study will be replicated and modified for application to the disaster mental health, spiritual care, and disability integration activities in addition to the current results. A meeting has been established with staff to discuss future implications on a local and regional level.

As presented in Figure 3, $82(90 \%)$ participants belonged to the 5 and below years of service group. These results indicate the importance of retention strategies, especially for those in the 5 and below years of service group. Closing the retention gap between the 5- and 10-year service groups is necessary to sustain HVs in the organization, which is best applied with the HVRP.

Hurricanes Hanna and Laura impacted the IVO during the implementation of this EBP project and was reported to have had property damages and losses beyond the capabilities of 
local and state governments, which was also compounded by a COVID-19 environment which required $\mathrm{HVs}$ to adhere to state and local regulations and mitigate exposures while attending medical needs of the disaster-stricken evacuees (Cornyn, 2020). Additionally, due to the hurricanes and 2020 pandemic, the virtual environment created an opportunity for added resources to be established. Other benefits are the inclusion of a scheduled discussion of the HVRP at each monthly meeting and annual training to improve the practice problem further and sustain the intervention. Evaluation of the effectiveness of the HVRP may also be integrated into the quarterly leadership meetings and annual strategic planning.

\section{Plans for Dissemination}

The dissemination strategies have been and continue to be formal and informal to suit the specific audience and intended purpose. Peer review was used to evaluate the HVRP and occurred at the local level with the interdisciplinary team, mentor, advisor, statistician, and writing coaches. Further peer review will be needed before manuscript dissemination in professional journals and organizations.

Briefings, summaries, and implementation guidelines were used to communicate results with stakeholders and HVs. A PowerPoint presentation describing the practice change of the HVRP was produced for the local and regional IVO. Representatives from this organization will use the presentation to inform new HVs. To enhance project sustainability, the HVRP is included in the DHS Orientation and monthly meeting agenda for new and existing HVs. A plan is in progress to replicate the HVRP and expand to other IVO activities. The EBP project will be submitted to the Scholarship and Open Access Repository website at the University of St. Augustine for Health Sciences. A link to the record page in SOAR@USA will be added to the author's social media account. Future students will be able to access the DNP scholarly project 
using the same link. Finally, a plan to publish in the Nonprofit and Voluntary Sector Quarterly is appropriate to reach leaders and members of volunteer organizations. Publication of the EBP project results will increase reader awareness of the HVRP benefits and retention determinants: mentoring, education and training, and social support through the Preparedness, Response, and Retention Phases.

\section{Conclusion}

The threat of hurricanes, fires, and other world disasters continue to plague humanity. (Keim et al., 2019). The pandemic of 2020 was a public emergency that challenged HVs in all capacities worldwide during this EBP project. Future opportunities to explore include collaboration with local healthcare organizations and colleges for event-based volunteers during disaster relief efforts. Healthcare volunteer response readiness implicates a need for retention to focus on mentoring, education and training, and social support (Salmani et al., 2019). Retention of this workforce is vital when responding to the health and wellness of the community, our country, and the world. 


\section{References}

Abbott, G. (2019, July 10). FEMA request letter and form. https://gov.texas.gov/uploads/files/press/FEMA_Request_Letter_and_Form_7.10.19.pdf

Afari-Asiedu, S., Asante, K. P., Senah, K., Abdulai, M. A., Afranie, S., Mahama, E., Anane, E. A., Abukari, M., Darko, M. L., Febir, L. G., \& Owusu-Agyei, S. (2018). Volunteering for health services in the middle part of Ghana: In whose interest? International Journal of Health Policy and Management, 7(9), 836-846. https://doi.org/10.15171/ijhpm.2018.38

Agency for Healthcare Research and Quality. (n.d.-a). Strength, weakness, opportunities, and threats. https://digital.ahrq.gov/health-it-tools-and-resources/evaluationresources/workflow-assessment-health-it-toolkit/all-workflow-tools/swot-analysis

Agency for Healthcare Research and Quality (n.d.-b). Topic: Evidence-based practice. https://www.ahrq.gov/topics/evidence-based-practice.html

Agency for Healthcare Research and Quality. (2018). Fillable Plan-Do-Study-Act (PDSA) tool for health care quality improvement (QI). https://www.ahrq.gov/evidencenow/tools/pdsaform.html\#: :text=The\%20Plan $\% 20$ Do $\% 20$ Study $\% 20$ Act,integrate $\% 20$ evidence $\% 20$ into $\% 20$ practice $\% 20$ procedures.

Albuquerque, S., Eriksson, A., \& Alvesson, H. M. (2018). The rite of passage of becoming a humanitarian health worker: Experiences of retention in Sweden. Global Health Action, 11(1), 1. https://doi.org/10.1080/16549716.2017.1417522

Alfes, K., Antunes, B., \& Shantz, A. D. (2017). The management of volunteers - What can human resources do? A review and research agenda. The International Journal of Human Resources Management, 28(1), 62-97. https://doi.org/10.1080/09585192.2016.1242508 
American Red Cross (2017). Volunteer handbook: A reference guide of general information and procedures for Red Cross volunteers.

https://intranet.redcross.org/content/dam/redcross/documents/our_services/volservices/prog-process-eval/volunteer-handbook.pdf

American Red Cross. (2019a). Disaster health services career path and training job tool:

Disaster cycle services job tools August 2019.

https://intranet.redcross.org/content/dam/redcross/documents/our_services/DisasterCycle

$\underline{\text { Services/des- }}$

capabilities/individual_clientservices/health_services/DHSCareerPathandTraining.pdf

American Red Cross. (2019b). Disaster health services standards and procedures: Disaster

cycle services standards and procedures/DCS SP RESPOND/disaster health services

August 2019.

https://intranet.redcross.org/content/dam/redcross/documents/our_services/DisasterCycle

$\underline{\text { Services/des- }}$

capabilities/individual_clientservices/health_services/DisasterHealthServicesStandardsA ndProcedures.pdf

American Red Cross. (2019c). Group/Activity/Position (GAP) Chart: Disaster cycle services job tools.

https://intranet.redcross.org/content/dam/redcross/documents/our_services/DisasterCycle

$\underline{\text { Services/core-and-pillar-processes/engage-volunteers-and- }}$

employees/GroupActivityPositionChart.pdf

American Red Cross. (2020a). Mission and values. https://www.redcross.org/about-us/who-weare/mission-and-values.html 
American Red Cross. (2020b). Red Cross nursing. https://www.redcross.org/about-us/who-weare/history/nursing.html

American Red Cross. (2020c). Texas Gulf Coast Region https://www.redcross.org/local/texas/gulf-coast/about-us/locations.html

Association of Quality. (2019). Learn about quality: Fishbone diagram. https://asq.org/qualityresources/fishbone

Chacon, F., Gutierrez, G., Sauto, V., Vecina, M. L., \& Perez, A. (2017). Volunteer functions inventory: A systematic review. Psicothema, 29(3), 306-316. doi:

10.7334/psicothema2016.371

Chatio, S., \& Akweongo, P. (2017). Retention and sustainability of community-based health volunteers' activities: A qualitative study in rural Northern Ghana. PloS One, 12(3), e0174002. https://doi.org/10.1371/journal.pone.0174002

Clary, E. G., Snyder, M., Ridge, R. D., Copeland, J., Stukas, A. A., Haugen, J., \& Miene, P. (1998). Understanding and assessing the motivations of volunteers: A functional approach. Journal of Personality and Social Psychology, 74, 1516-1530. https://pdfs.semanticscholar.org/b46a/11a4464f77b64492e2c2b688d9ebcc3c5565.pdf

Cornyn, J. (2020). Following Hurricanes Laura and Hanna, Cornyn, Cruz urges POTUS to issue federal disaster declaration for Texas. https://www.cornyn.senate.gov/content/news/following-hurricanes-laura-and-hanna$\underline{\text { cornyn-cruz-urge-potus-issue-federal-disaster }}$

Dang, D., \& Dearholt, S. (2017). Johns Hopkins nursing evidence-based practice: model and guidelines. 3rd ed. Indianapolis, IN: Sigma Theta Tau International. https://www.hopkinsmedicine.org/evidence-based-practice/ijhn_2017_ebp.html 
Gutierrez, C. (2019). Special report: Historic valley flooding. httpsfwww.krgv.com/news/special-report-historic-valley-flooding/

Haski, L. D., Meijs, L. C. P. M., Lockstone, B. L., Holmes, K., \& Oppenheimer, M. (2018). Measuring volunteerability and the capacity to volunteer among non-volunteers: Implications for social policy. Social Policy \& Administration, 52(5), 1139-1167.

\section{https://doi.org/10.1111/spol.12342}

Institute for Healthcare Improvement. (2020). Plan-Do-Study-Act (PDSA) Worksheet. Retrieved May 22, 2020 from http://www.ihi.org/resources/Pages/Tools/PlanDoStudyActWorksheet.aspx

Iowa Model Collaborative. (2017). Iowa model of evidence-based practice: Revisions and validation. Worldviews on Evidence-Based Nursing, 14(3), 175-182. https://doi.org/10.1111/wvn.12223

Insurance Information Institute. (2020). Facts + statistics: U.S. catastrophes. Retrieved May 22, 2020, from https://www.iii.org/fact-statistic/facts-statistics-us-catastrophes

Keim, M. E., Kirsch, T. D., Alleyne, O., Benjamin, G., DeGutis, L., Dyjack, D., \& Burkle, F. M. (2019). The need for a national strategy to assess and reduce disaster-related mortality in the United States. American Journal of Public Health, 109(4), 539-540. https://doi.org/10.2105/AJPH.2019.304975

Kim, E. J., Fox, S., Moretti, M. E., Turner, M., Girard, T. D., \& Chan, S. Y. (2019). Motivations and barriers associated with physician volunteerism for an international telemedicine organization. Frontiers in Public Health, 7, 224.

https://doi.org/10.3389/fpubh.2019.00224 
Lewin, K. (1947). Frontier in group dynamics: Concept, method, and reality in social science; Social equilibrium and social change. Human Relations, 1(1), 4-51. https://doi.org/10.1177/001872674700100103

Mays, D. C., O'Neil, E. J., Jr, Mworozi, E. A., Lough, B. J., Tabb, Z. J., Whitlock, A. E., Mutimba, E. M., \& Talib, Z. M. (2017). Supporting and retaining village health teams: An assessment of a community health worker program in two Ugandan districts. International Journal for Equity in Health, 16(1), 129. https://doi.org/10.1186/s12939-017-0619-6

McGeehan, L., Takehara, M. A., \& Daroszewski, E. (2017). Physicians' perceptions of volunteer service at safety-net clinics. The Permanente Journal, 21, 16-003. https://doi.org/10.7812/TPP/16-003

Meyer, M. A., Peek, L., Unnithan, N. P., Coşkun, R., Tobin-Gurley, J., \& Hoffer, K. H. (2016). Planning for diversity: Evaluation of a volunteer disaster response program. Journal of Cultural Diversity, 23(3), 106-113.

Mlotshwa, L., Harris, B., Schneider, H., \& Moshabela, M. (2015). Exploring the perceptions and experiences of community health workers using role identity theory. Global Health Action, 8, 28045. https://doi.org/10.3402/gha.v8.28045

Moghaddam, H. R., Allahverdipour, H., \& Matlabi, H. (2018). Successful recruitment and retention strategies for women health volunteers: Viewpoints of the volunteers' supervisors and relevant researchers. Journal of Multidisciplinary Healthcare, 11, 621634. https://doi.org/10.2147/JMDH.S180544 
Moher, D., Liberati, A., Tetzlaff, J., Altman, D.G., \& The PRISMA Group (2009). Preferred Reporting Items for Systematic Reviews and Meta-Analyses: The PRISMA Statement. PLoS Med 6(7), e1000097. https://doi.org/10.1371/journal.pmed.1000097

Ngilangwa, D. P., \& Mgomella, G. S. (2018). Factors associated with retention of community health workers in maternal, newborn, and child health programme in Simiyu Region, Tanzania. African Journal of Primary Health Care \& Family Medicine, 10(1), e1-e8.

\section{https://doi.org/10.4102/phcfm.v10i1.1506}

Ngugi, A. K., Nyaga, L. W., Lakhani, A., Agoi, F., Hanselman, M., Lugogo, G., \& Mehta, K. M. (2018). Prevalence, incidence, and predictors of volunteer community health worker attrition in Kwale County, Kenya. British Medical Journal Global Health, 3(4), e000750. https://doi.org/10.1136/bmjgh-2018-000750

Nothwehr, F., \& Rohlman, D. (2019). Employer-supported volunteerism in rural worksites. Workplace Health \& Safety, 67(10), 512-519. https://doi.org/10.1177/2165079919862295

O’Donohue, W., Martin, A., \& Torugsa, N. (2015). Understanding individual responses to failure by the organisation to fulfill its obligations: Examining the influence of psychological capital and psychological contract type. Human Resource Management Journal, 25(1), 131-147. https://doi.org/10.1111/1748-8583.12055

Omoto, A. M., \& Packard, C. D. (2016). The power of connections: Psychological sense of community as a predictor of volunteerism. Journal of Social Psychology, 156(3), 272290.

Ortega Carpio, M. L., Martinez-Cousinou, G., \& Morales-Fernández, E. J. (2018). Transformative volunteerism: An inventory of NGDO volunteers' motivations. Human 
Service Organizations: Management, Leadership \& Governance, 42(1), 33-52. https://doi.org/10.1080/23303131.2017.1363103

Salmani, I., Seyedin, H., Ardalan, A., \& Farajkhoda, T. (2019). Conceptual model of managing health care volunteers in disasters: A mixed-method study. Bio-Med Central Health Services Research, 19(1), 241. https://doi.org/10.1186/s12913-019-4073-6

Sarti, A. J., Sutherland, S., Landriault, A., DesRosier, K., Brien, S., \& Cardinal, P. (2017). Exploring the components of physician volunteer engagement: A qualitative investigation of a national Canadian simulation-based training programme. British Medical Journal Open, 7(6), e014303. https://doi.org/10.1136/bmjopen-2016-014303

Smith, S. L., \& Grove, C. J. (2017). Bittersweet and paradoxical. Nonprofit Management \& Leadership, 27(3), 353-369. https://doi.org/10.1002/nml.21250

Trevizo, P. (2020). Holistic Houston: In the wake of Hurricane Harvey the city is redefining its approach to resilience planning. Planning, 86(1), 30.

Vareilles, G., Marchal, B., Kane, S., Petrič, T., Pictet, G., \& Pommier, J. (2015). Understanding the motivation and performance of community health volunteers involved in the delivery of health programmes in Kampala, Uganda: A realist evaluation. British Medical Journal open, 5(11), e008614. https://doi.org/10.1136/bmjopen-2015-008614

Wilson, J., \& Son, J. (2018). The connection between neighboring and volunteering. City \& Community, 17(3), 720-736. https://doi.org/10.1111/cico.12324 
Table 1

Budget

\begin{tabular}{|c|c|l|}
\hline Expenses & Cost & \multicolumn{1}{|c|}{ Description } \\
\hline Indirect costs & & \\
\hline Training & $\$ 0.00$ & Volunteers are non-paid workers \\
\hline Supplies & $\$ 23.00$ & Cards, envelopes, and stamps \\
\hline Gift Cards & $\$ 145.00$ & $\$ 5.00$ for each survey completed \\
\hline Total Expenses & $\$ 168.00$ & \\
\hline
\end{tabular}




\section{Figure 1}

Healthcare Volunteer Retention Program

PRISMA 2009 Flow Diagram
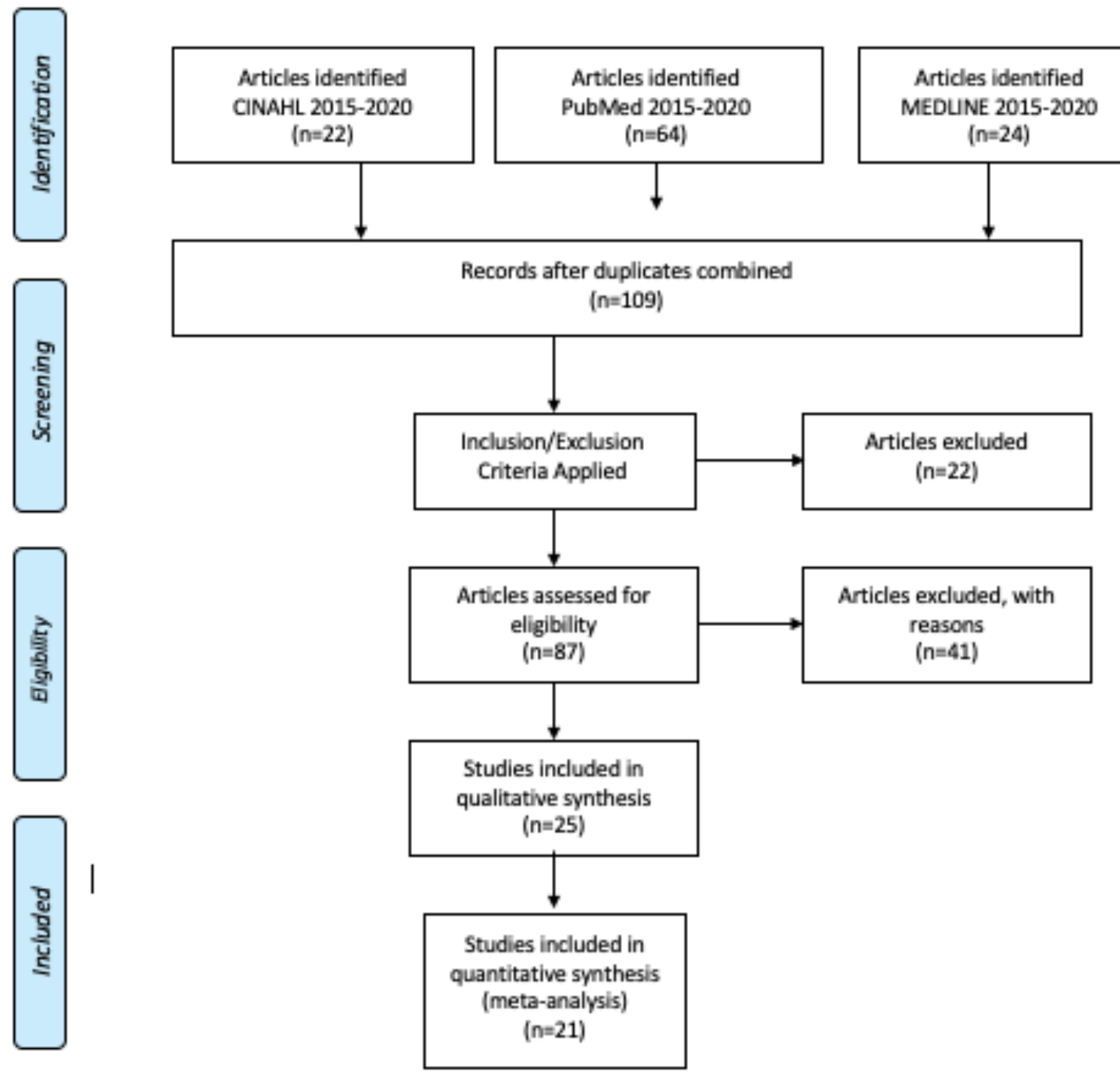

Moher, D., Liberati, A., Tetzlaff, J., Altman, D.G., \& The PRISMA Group (2009). Preferred Reporting Items for Systematic Reviews and Meta-Analyses: The PRISMA Statement. PLoS Med 6(7), e1000097. https://doi.org/10.1371/journal.pmed.1000097 


\section{Appendix A}

\section{Healthcare Volunteer Retention Program}

\begin{tabular}{|l|l|}
\hline Volunteer Name & Mentor Name \\
\hline Phone number/email & Phone number/email \\
\hline Chapter/Region & Chapter/Region \\
\hline Date Started Assignment & Assignment \\
\hline
\end{tabular}

\section{Purpose}

This program will guide the mentor and volunteer in navigating through the preparedness, response, and retention phases of the volunteer service to influence retention, intent to stay, and volunteer satisfaction. This healthcare volunteer retention program (HVRP) is to be used in collaboration with the organization's existent volunteer handbook, standards and procedures, job descriptions, and career path and training job tools. Mentoring during these three phases is vital to the retention program.

A. Preparedness Phase: Onboarding, education, training, and competency are vital to the success of the healthcare volunteer.

1. A mentor is assigned at the beginning of this phase to guide the volunteer through the completion of important tasks.

2. The first meeting with the volunteer for the welcome and service station orientation will occur within 1-2 weeks.

3. The mentor will review tasks within the Preparedness Phase during the first 30 days.

4. The Preparedness Phase sets the foundation for self-confidence during the response phase.

B. Response Phase: Mentoring produces a well-prepared and informed volunteer who is disaster-ready.

1. The volunteer discloses the engagement schedule, plans activities, and reviews the workload.

2. The volunteer has the necessary tools, training, resources, and opportunities to improve the volunteer experience during this phase.

3. Feedback from the mentor is an important part of evaluating the volunteer's performance during a response mission. This is a two-way conversation.

4. During the Response Phase, the volunteer may decide to improve the performance within the assigned position or develop a new skill set.

C. Retention Phase: Social Support is vital to the health and well-being of the volunteer.

1. A review of the Work-Life-Volunteer Balance is important for wellness.

2. A discussion about promotion opportunities within the organization and the next steps allows the volunteer the autonomy to make decisions on their volunteer career path.

3. Social Support is evident within the workgroup or is explored.

4. A review of the types of recognition and rewards within the organization allows the volunteer to feel appreciated

5. Personal growth and development are discussed with the volunteer.

6. Planning for the end of volunteer service is also important for succession planning 
7. Annual Training, Evaluations, and new trainings are a continuum to the Preparedness Phase.

\section{Instructions}

1. This electronic form intends to guide the volunteer and mentor.

2. This guide has three phases: Preparedness Phase, Response Phase, and Retention Phase.

3. Each phase has a list of tasks. The mentor may adjust and add items to each phase to individualize the program.

4. The volunteer will review each task independently and/or with a mentor and then check each box when complete. Virtual options are available through the organization's technology and email system.

5. The mentor will review each section, offer support, and check the box when complete.

6. This retention program will be reviewed at 30/60/90 days.

\begin{tabular}{|c|c|}
\hline Preparedness Phase & $\begin{array}{l}\text { Onboarding, education, training, and competency are vital to the } \\
\text { success of the healthcare volunteer. Preparedness sets the foundation } \\
\text { for self-confidence during the response phase. }\end{array}$ \\
\hline Volunteer & $\begin{array}{l}\square \text { Receives a Leadership Welcome } \\
\square \text { Receives a mentor assigned to ease steps toward the next phase } \\
\square \text { Attends orientation. } \\
\square \text { Completes pre-requisites for assignment } \\
\square \text { Documents monthly volunteer hours }\end{array}$ \\
\hline Mentor & $\begin{array}{l}\square \text { Initiates communication with volunteer } \\
\square \text { Encourages peer collaboration } \\
\square \text { Checks in at least monthly to review milestones (i.e. submission of } \\
\text { volunteer hours, training \& technology support, goal setting) }\end{array}$ \\
\hline
\end{tabular}

\begin{tabular}{|c|c|c|}
\hline Preparedness Phase & Volunteer & Mentor \\
\hline $\begin{array}{l}\text { Welcome! Get to } \\
\text { know your service } \\
\text { station. }\end{array}$ & $\begin{array}{l}\square \quad \text { Welcome contact with the mentor } \\
\square \quad \text { Introduction to the organization through email, } \\
\text { virtually, or in-person } \\
\square \quad \text { Received Map of Region } \\
\square \quad \text { Received access and tour the building } \\
\square \quad \text { Service Station Safety } \\
\square \quad \text { Understanding the communication system by phone, } \\
\text { text, email, and/or other means } \\
\square \quad \text { Review the use of office equipment } \\
\square \quad \text { Review the use of fleet } \\
\square \quad \text { Documentation of volunteer hours }\end{array}$ & $\square$ \\
\hline $\begin{array}{l}\text { Volunteer Handbook } \\
\text { and other pertinent } \\
\text { documents. }\end{array}$ & $\begin{array}{ll}\square & \text { Review of Volunteer Handbook } \\
\square & \text { Volunteer Policies \& procedures } \\
\square & \text { Attire and ID }\end{array}$ & $\square$ \\
\hline $\begin{array}{l}\text { Register and } \\
\text { complete the required } \\
\text { trainings. }\end{array}$ & $\begin{array}{ll} & \text { Training Point of Contact } \\
\square & \text { Registered for training } \\
\square & \text { Completed onboarding training } \\
\square & \text { Reviewed questions/issues/concerns }\end{array}$ & $\square$ \\
\hline
\end{tabular}




\begin{tabular}{|c|c|c|}
\hline Preparedness Phase & Volunteer & Mentor \\
\hline $\begin{array}{l}\text { Get to know your } \\
\text { organizational } \\
\text { structure. }\end{array}$ & $\begin{array}{ll}\square & \text { National } \\
\square & \text { Divisional } \\
\square & \text { Regional } \\
\square & \text { Territory/Chapter } \\
\square & \text { Lines of Service }\end{array}$ & $\square$ \\
\hline $\begin{array}{l}\text { Review your position } \\
\text { description, role, } \\
\text { responsibilities, team } \\
\text { communication, and } \\
\text { meet others. }\end{array}$ & $\begin{array}{ll}\square & \text { Group } \\
\square & \text { Activity } \\
\square & \text { Position } \\
\square & \text { Supervisor: } \\
\square & \text { Program Manager } \\
\square & \text { My Team } \\
\square & \text { My Tools } \\
\square & \text { Staff Directory received } \\
\square & \text { Team 1 (add as needed) }\end{array}$ & $\square$ \\
\hline $\begin{array}{l}\text { Explore technology } \\
\text { and systems for } \\
\text { access and resources. }\end{array}$ & $\begin{array}{ll}\square & \text { Volunteer services key terms \& definitions } \\
\square & \text { Review computer policies } \\
\square & \text { Access to the organization email } \\
\square & \text { Access to the volunteer portal } \\
\square & \text { Access to volunteer share point } \\
\square & \text { Access the Learning Management System } \\
\square & \text { Customer Portal / Password Self Service }\end{array}$ & $\square$ \\
\hline Scheduled Reviews & $\begin{array}{ll}\square & 30 \text { Day Review } \\
\square & 60 \text { Day Review } \\
\square & 90 \text { Day Review }\end{array}$ & $\square$ \\
\hline
\end{tabular}

\begin{tabular}{|l|c|}
\multicolumn{1}{|c|}{ Response Phase } & $\begin{array}{c}\text { Transition to the response phase occurs when the mentor-supported } \\
\text { volunteer has met the requirements for the assignment. }\end{array}$ \\
\hline Volunteer & $\square$ Receives assignment \\
& $\square$ Mission Ready \\
& $\square$ Mission Moments \\
& $\square$ Documents monthly volunteer hours \\
\hline Mentor & $\square$ Monthly communication by text, call, or email \\
& $\square$ Supports mission readiness and debriefing \\
& $\square$ Reviews safety, health, and wellness \\
\hline
\end{tabular}

Response Phase

Volunteer planned engagement

\section{Volunteer}

$\square \quad$ Number of planned volunteer days/hours

$\square \quad$ List of projects or activities

$\square \quad$ Virtual or in-person

$\square$ Discuss flexibility, adaptability, \& opportunities

$\square \quad$ Review response services, workload, \& support

\section{Logistics}

Identified need for: $\square$ Tools

$\square \quad$ Training

$\square$ Resources

$\square$ Opportunities to improve the experience

Mentor 


\begin{tabular}{|l|c|}
\hline \multicolumn{1}{|c|}{ Retention Phase } & $\begin{array}{l}\text { Ongoing promotion opportunities within the organization, personal } \\
\text { growth and development, social support, recognition, and rewards are } \\
\text { vital to volunteer retention, intent to stay, and satisfaction. }\end{array}$ \\
\hline Volunteer & $\begin{array}{l}\square \text { Opportunities to lead/teach/mentor } \\
\\
\end{array}$ \\
& $\square$ Steps / Promotions achieved \\
& $\square$ Documents monthly volunteer hours \\
\hline Mentor & $\square$ Monthly communication by text, call, or email \\
& $\square$ Introduces volunteer to opportunities to lead/teach/mentor \\
& $\square$ Discusses promotions \\
& $\square$ Supports ongoing education, retention, and volunteer satisfaction \\
\hline
\end{tabular}

\begin{tabular}{|c|c|c|}
\hline Retention Phase & Volunteer & Mentor \\
\hline $\begin{array}{l}\text { Safety, Health, and } \\
\text { Wellness }\end{array}$ & $\begin{array}{ll}\square & \text { Review safety } \\
\square & \text { Review health } \\
\square & \text { Review wellness } \\
\square & \text { Work-Life-Volunteer Balance }\end{array}$ & $\square$ \\
\hline $\begin{array}{l}\text { Promotion } \\
\text { opportunity }\end{array}$ & $\begin{array}{ll} & \text { Identify promotion opportunities } \\
\square \quad \text { Next Steps }\end{array}$ & $\square$ \\
\hline Social Support & $\begin{array}{ll}\square & \text { Events within the organization } \\
\square & \text { Events in the community } \\
\square & \text { Social media }\end{array}$ & $\square$ \\
\hline $\begin{array}{l}\text { Recognition and } \\
\text { Rewards }\end{array}$ & $\begin{array}{ll}\square & \text { Personal volunteer recognition preference } \\
\square & \text { Awards/Pins/Certificates } \\
\square & \text { Recognition/Nominations }\end{array}$ & $\square$ \\
\hline $\begin{array}{l}\text { Personal Growth \& } \\
\text { Development }\end{array}$ & $\begin{array}{ll}\square & \text { Values } \\
\square & \text { Understanding } \\
\square & \text { Enhancement } \\
\square & \text { Career } \\
\square & \text { Social } \\
\square & \text { Protective } \\
\square & \text { Survey }\end{array}$ & $\square$ \\
\hline Annual Training & $\begin{array}{ll}\square \quad \text { Review annually scheduled training } \\
\square \quad \text { Attend Year }\end{array}$ & $\square$ \\
\hline Annual evaluations & $\begin{array}{ll}\square & \text { Review the evaluation process } \\
\square & \text { Review questions/issues/concerns }\end{array}$ & $\square$ \\
\hline New Training & $\begin{array}{ll} & \text { Review new training } \\
\square & \text { Attend Year }\end{array}$ & $\square$ \\
\hline $\begin{array}{l}\text { End of Volunteer } \\
\text { Service }\end{array}$ & $\begin{array}{ll}\square & \text { Review voluntary termination } \\
\square & \text { If leaving: Reason } \\
\square & \text { Review involuntary termination } \\
\square & \text { Process for exit interview } \\
\square & \text { Review questions/issues/concerns } \\
\square & \text { Survey }\end{array}$ & $\square$ \\
\hline
\end{tabular}




\section{Appendix B}

\section{Approval Letter for VFI Tool}

Subject: Re: Permission to use VFI

Date: Wednesday, May 27, 2020 at 9:16:03 AM Central Daylight Time

From: Mark Snyder <msnyder@umn.edu>

To: Sandra Gomez<S.Gomez1@usa.edu>

Dear Sandra Gomez,

You have our permission to use the Volunteer Functions Inventory in your evidence-based project on healthcare worker retention.

We hope your project goes well, and look forward to learning about your findings.

Best wishes,

Mark Snyder

On Tue, May 26, 2020 at 10:08 PM Sandra Gomez <S.Gomez1@usa.edu> wrote:

Sirs,

I hope this email finds you well.

I am writing to request permission to utilize the Volunteer Functions Inventory tool in an evidence-based practice change project called "Healthcare Worker Retention Program: Improving Healthcare Worker Retention in a Volunteer Organization"

Very Respectfully,

Sandra Gomez, MSN, RN

Post-Professional Student

MSN to DNP

University of Saint Augustine for Health Sciences

School of Nursing

Email: s.gomez1@usa.edu

Cell: 956-292-1587 (CST time zone)

$-$

Mark Snyder

McKnight Presidential Chair in Psychology

Director, Center for the Study of the Individual and Society

University of Minnesota

75 East River Road

Minneapolis, MN 55455

(612) 625-1507 (voice)

(612) 626-2079 (fax)

msnyderQumn.edu (e-mail) 


\title{
Appendix C
}

\author{
The Functional Approach to Volunteers' Motivations \\ Gil Clary and Mark Snyder \\ College of St, Catherine University of Minnesota
}

\section{Assumptions}

1. People are purposeful, planful, goal-directed -- Volunteers engage in volunteer work in order to satisfy important personal goals

2. Different people may do similar things for different reasons - Volunteers performing the same volunteer activity for the same organization may have different reasons for volunteering

3. Any one individual may be motivated by more than one need or goal - An individual volunteer may be attempting to satisfy two or more motives through one activity at your organization

4. Outcomes depend on the matching of needs and goals to the opportunities afforded by the environment - Successful volunteer recruitment, satisfaction, and retention is tied to the ability of the volunteer experience to fulfil the volunteer's important motives

\section{The Motivations for Volunteering}

Values function the person is volunteering in order to express or act on important values, such as humanitarianism and helping the less fortunate

Understanding function the volunteer is seeking to learn more about the world and/or exercise skills that are often unused

Enhancement function the individual is seeking to grow and develop psychologically through involvement in volunteering

Career function

the volunteer has the goal of gaining career-related experience through volunteering

Social function volunteering allows the person to strengthen one's social relationships

Protective function the individual uses volunteering to reduce negative feelings, such as guilt, or to address personal problems 


\section{VOLUNTEERISM QUESTIONNAIRE}

Your organization is involved in a project related to volunteer's reasons and experiences with volunteering. On the following pages are two sets of items that concern your experiences as a volunteer with this organization. The first set, Reasons for Volunteering, presents 30 reasons that people volunteer and asks that you indicate how important each reason is for you for your volunteering at this organization. The second set, Volunteering Outcomes, presents 18 outcomes that can result from volunteering and asks that you indicate whether you have experienced each outcome. You do not need to put your name on the questionnaire.

\section{Reasons for Volunteering}

Using the 7-point scale below, please indicate how important or accurate each of the following possible reasons for volunteering is for you in doing volunteer work at this organization. Record your answer in the space next to each item.

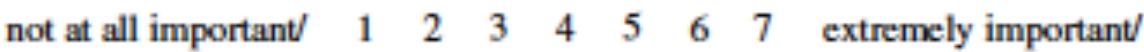
accurate for you accurate for you

$\underline{\text { Rating }}$

1. Volunteering can help me get my foot in the door at a place where I'd like to work

2. My friends volunteer.

3. I am concemed about those less fortunate than myself.

4. People I'm close to want me to volunteer.

5. Voluntering makes me feel important

6. People I know share an interest in community service.

7. No matter how bad I've been feeling, volunteering helps me to forget about it.

8. I am genuinely concerned about the particular group I am serving.

9. By volunteering, I feel less lonely.

10. I can make new contacts that might help my business career.

11. Doing volunteer work relieves me of some of the guilt over being more fortunate than others.

12. I can leam more about the cause for which I am working.

13. Volunteering increases my self-esteem.

14. Volunteering allows me to gain a new perspective on things.

15. Volunteering allows me to explore different career options.

16. I feel compassion toward people in need.

17. Others with whom I am close place a high value on community service.

18. Volunteering kets me learn through direct "hands on" experience. 
$\begin{array}{lll}\text { - } & 19 . & \text { I feel it is important to help others. } \\ \text { - } & 20 . & \text { Volunteering helps me work through my own personal problems. } \\ \text { - } & 21 . & \text { Voluntering will help me succeed in my chosen profession. } \\ \text { - } & 22 . & \text { I can do something for a cause that is important to me. } \\ - & 23 . & \text { Volunteering is an important activity to the people I know best. } \\ - & 24 . & \text { Volunteering is a good escape from my own troubles. } \\ - & 25 . & \text { I can leam how to deal with a variety of people. } \\ - & 26 . & \text { Voluntering makes me feel needed. } \\ - & 27 . & \text { Voluntering makes me feel better about myself. } \\ - & 28 . & \text { Volunteering experience will look good on my resume. } \\ - & 29 . & \text { Volunteering is a way to make new friends. } \\ - & 30 . & \text { I can explore my own strengths. }\end{array}$

\section{Volunteering Outcomes}

Using the 7-point scale below, please indicate the amount of agreement or disagreement you personally feel with each statement. Please be as accurate and honest as possible, so we can better understand this organization.

Rating

$$
\begin{array}{llllllllll}
\text { Strongly Disagree } & 1 & 2 & 3 & 4 & 5 & 6 & 7 & \text { Strongly Agree }
\end{array}
$$

31. In volunteering with this organization, I made new contacts that might help my business or career.

- 32. People I know best know that I am volunteering at this organization.

- 33. People I am genuinely concerned about are being helped through my volunteer work at this organization.

- 34. From volunteering at this organization, I feel better about myself.

- 35. Volunteering at this organization allows me the opportunity to escape some of my own troubles.

- 36. I have learned how to deal with a greater variety of people through volunteering at this organization.

- 37. As a volunteer in this organization, I have been able to explore possible career options.

- 38. My friends found out that I am volunteering at this organization.

- 39. Through volunteering here, I am doing something for a cause that I believe in.

- 40. My self-esteem is enhanced by performing volunteer work in this organization. 
- 41. By volunteering at this organization, I have been able to work through some of my own personal problems.

- 42. I have been able to kearn more about the cause for which I am working by volunteering with this organization.

- 43. I am enjoying my volunteer experience.

- 44. My volunteer experience has been personally fulfilling.

- 45. This experience of volunteering with this organization has been a worthwhile one.

- 46. I have been able to make an important contribution by volunteering at this organization.

- 47. I have accomplished a great deal of "good" through my volunteer work at this organization.

48. One year from now, will you be (please circle your best guess as of today):
A. volunteering at this organization.
B. volunteering at another organization
C. not voluntering at all. 


\section{SCORING SHEET}

Volunteer \#

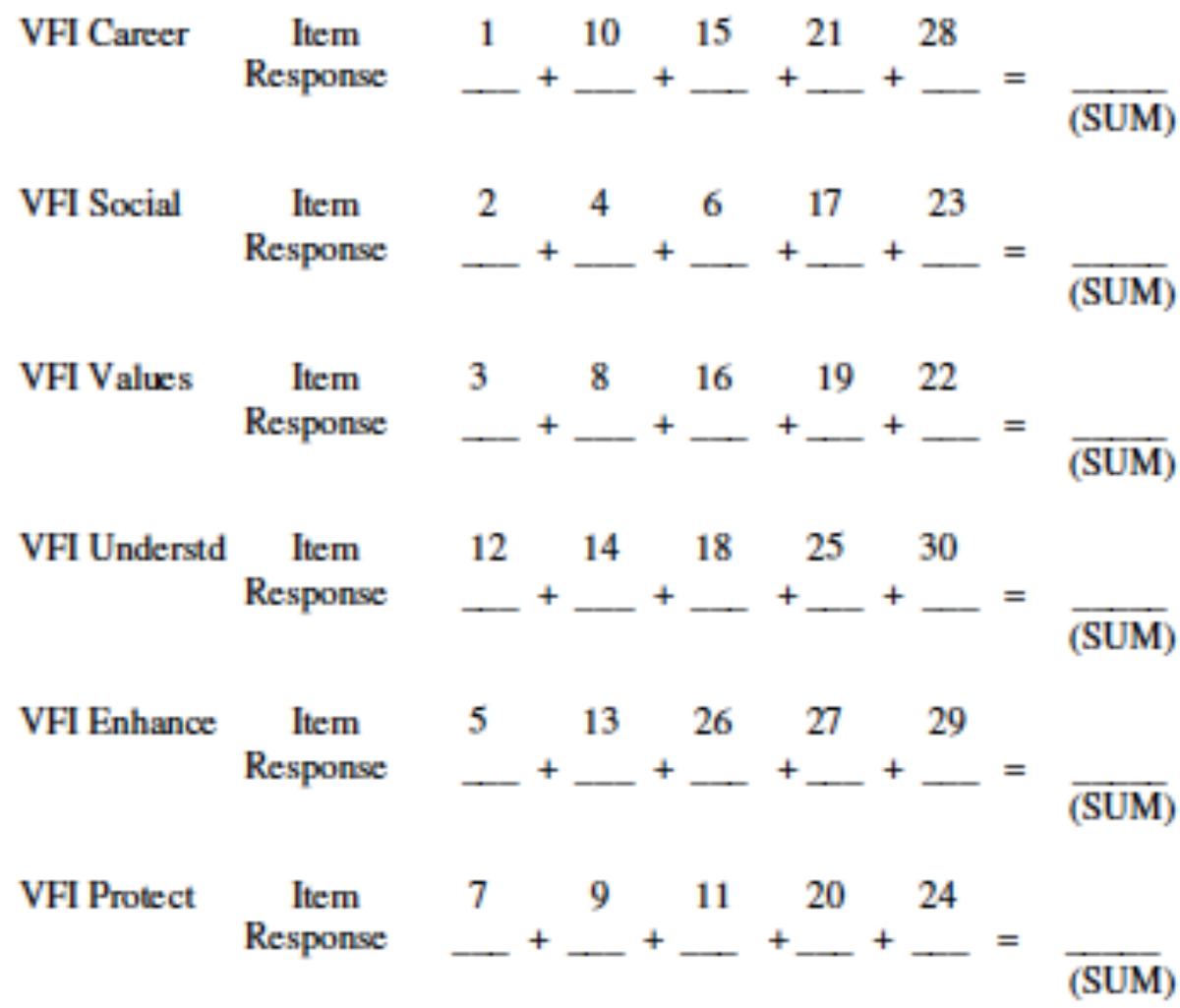

Outcomes Career (Add items 31 and 37) $\ldots+\ldots=$

Outcomes Social (Add items 32 and 38) $\ldots+\ldots=$

Outcomes Values (Add items 33 and 39) __ $+\ldots$

Outcomes Enhance (Add items 34 and 40) $\ldots+\ldots=$

Outcomes Protect (Add items 35 and 41) _ $+\ldots=$

Outcomes Understd (Add items 36 and 42) __ $+\ldots$

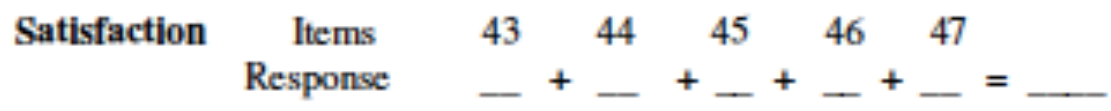

Long-term Intentions (item 48) 


$$
\begin{aligned}
& \mathrm{C}=\text { Career } \\
& \mathrm{Sc}=\text { Social } \\
& \mathrm{V}=\text { Values } \\
& \mathrm{E}=\text { Enhancement } \\
& \mathrm{P}=\text { Protective } \\
& \mathrm{U}=\text { Understanding } \\
& \mathrm{St}=\text { Satisfaction }
\end{aligned}
$$

\section{Volunteering Outcomes}




\section{Appendix D}

\section{Summary of Primary Research Evidence}

\begin{tabular}{|c|c|c|c|c|c|c|}
\hline Citation & Question & $\begin{array}{l}\text { Design/ } \\
\text { Tools/ } \\
\text { Sample Size/ } \\
\text { Evidence } \\
\text { Level/Quality }\end{array}$ & $\begin{array}{l}\text { Usefulness } \\
\text { Results } \\
\text { Key Findings }\end{array}$ & $\begin{array}{l}\text { Recommendati } \\
\text { ons/ } \\
\text { Implications }\end{array}$ & $\begin{array}{l}\text { Theoretical } \\
\text { Foundation }\end{array}$ & $\begin{array}{l}\text { Outcome } \\
\text { Definition }\end{array}$ \\
\hline $\begin{array}{l}\text { Afari-Asiedu, S., Asante, K. P., Senah, } \\
\text { K., Abdulai, M. A., Afranie, S., } \\
\text { Mahama, E., Anane, E. A., Abukari, M., } \\
\text { Darko, M. L., Febir, L. G., \& Owusu- } \\
\text { Agyei, S. (2018). Volunteering for } \\
\text { health services in the middle part of } \\
\text { Ghana: In whose interest? International } \\
\text { Journal of Health Policy and } \\
\text { Management, 7(9), 836-846. } \\
\text { https://doi.org/10.15171/ijhpm.2018.38 }\end{array}$ & $\begin{array}{l}\text { To find } \\
\text { what } \\
\text { motivates } \\
\text { community- } \\
\text { based } \\
\text { volunteers. }\end{array}$ & $\begin{array}{l}\text { Design: } \\
\text { Sequential } \\
\text { mixed method; } \\
\text { cross-sectional } \\
\text { survey. } \\
\text { Tools: a } \\
\text { crossed } \\
\text { sectional } \\
\text { survey. } \\
\text { Qualitative } \\
\text { interviews: in- } \\
\text { depth } \\
\text { interviews and } \\
\text { focus group } \\
\text { discussion. } \\
\text { Sample Size: } \\
\text { 205 } \\
\text { community- } \\
\text { based } \\
\text { volunteers. } \\
\text { Evidence/Gra } \\
\text { de: } \\
\text { Level I -A }\end{array}$ & $\begin{array}{l}\text { Personal interest } \\
\text { and community } \\
\text { leader's selection } \\
\text { of } \\
\text { volunteers=key } \\
\text { reasons. } \\
\text { Motivations (t- } \\
\text { shirts, bags, food } \\
\text { during trainings, } \\
\text { community } \\
\text { recognition, } \\
\text { social prestige. }\end{array}$ & $\begin{array}{l}\text { Motivators: } \\
\text { Personal } \\
\text { interests. } \\
\text { Monetary and } \\
\text { non-monetary } \\
\text { incentives. } \\
\text { Recognition }\end{array}$ & $\begin{array}{l}\text { The Social } \\
\text { Exchange } \\
\text { Theory. }\end{array}$ & $\begin{array}{l}\text { Motivation } \\
\text { and retention } \\
\text { were } \\
\text { influenced } \\
\text { by personal } \\
\text { interests in } \\
\text { form of } \\
\text { recognition } \\
\text { by the } \\
\text { community } \\
\text { the provision } \\
\text { of non- } \\
\text { monetary } \\
\text { and } \\
\text { monetary } \\
\text { incentives, }\end{array}$ \\
\hline
\end{tabular}




\begin{tabular}{|c|c|c|c|c|c|c|}
\hline $\begin{array}{l}\text { Albuquerque, S., Eriksson, A., \& } \\
\text { Alvesson, H. M. (2018). The rite of } \\
\text { passage of becoming a humanitarian } \\
\text { health worker: Experiences of retention } \\
\text { in Sweden. Global Health Action, 11(1), } \\
\text { 1. } \\
\underline{\text { https://doi.org/10.1080/16549716.2017. }} \\
\underline{1417522}\end{array}$ & $\begin{array}{l}\text { To find } \\
\text { what } \\
\text { motivates } \\
\text { and } \\
\text { supports } \\
\text { experienced } \\
\text { humanitaria } \\
\text { n health } \\
\text { workers to } \\
\text { remain } \\
\text { engaged. }\end{array}$ & $\begin{array}{l}\text { Design: Semi- } \\
\text { structured } \\
\text { interviews. } \\
\text { Research } \\
\text { Tools Used: } \\
\text { methodology } \\
\text { of content } \\
\text { analysis } \\
\text { Sample } \\
\text { Size:10 HVs } \\
\text { in } 3 \text { missions } \\
\text { Data } \\
\text { Analysis: } \\
\text { Social } \\
\text { dimensions of } \\
\text { transformation } \\
\text {. } \\
\text { Evidence/Gra } \\
\text { de: Level II-B }\end{array}$ & $\begin{array}{l}\text { Social supports } \\
\text { are important to } \\
\text { facilitate rites of } \\
\text { passage during } \\
\text { humanitarian } \\
\text { missions. }\end{array}$ & $\begin{array}{l}\text { The experience } \\
\text { and assistance } \\
\text { during } \\
\text { deployment and } \\
\text { after having a } \\
\text { great impact on } \\
\text { the long-term } \\
\text { commitment of a } \\
\text { volunteer. } \\
\text { Strengthen } \\
\text { strategies to } \\
\text { facilitate long- } \\
\text { term } \\
\text { commitment. }\end{array}$ & $\begin{array}{l}\text { Gennep's } \\
\text { Theory } \\
\text { "Rites of } \\
\text { Passage" }\end{array}$ & $\begin{array}{l}\text { Personal } \\
\text { goals and the } \\
\text { principle of } \\
\text { assisting } \\
\text { others during } \\
\text { and after } \\
\text { deployment } \\
\text { is significant. }\end{array}$ \\
\hline $\begin{array}{l}\text { Chatio, S., \& Akweongo, P. (2017). } \\
\text { Retention and sustainability of } \\
\text { community-based health volunteers' } \\
\text { activities: A qualitative study in rural } \\
\text { Northern Ghana. PloS One, 12(3), } \\
\text { e0174002. } \\
\text { https://doi.org/10.1371/journal.pone.017 } \\
\underline{4002}\end{array}$ & $\begin{array}{l}\text { Explore } \\
\text { factors } \\
\text { affecting } \\
\text { retention } \\
\text { and } \\
\text { sustainabilit } \\
\text { y of CBHV } \\
\text { activities. }\end{array}$ & $\begin{array}{l}\text { Design: a } \\
\text { qualitative } \\
\text { study } \\
\text { Tools: in- } \\
\text { depth } \\
\text { interviews, } \\
\text { NVivo 10 } \\
\text { software } \\
\text { Sample Size: } \\
32 \\
\text { Evidence/Gra } \\
\text { de Level II-B }\end{array}$ & $\begin{array}{l}\text { Desire to help, } \\
\text { prestige, } \\
\text { recognition } \\
\text { motivated them } \\
\text { to work as } \\
\text { healthy } \\
\text { volunteers. Lack } \\
\text { of incentives and } \\
\text { supplies affected } \\
\text { work. }\end{array}$ & $\begin{array}{l}\text { Community } \\
\text { support, } \\
\text { incentives, } \\
\text { logistical } \\
\text { supplies, awards } \\
\text { are a mechanism } \\
\text { to retain and } \\
\text { sustain CBHV }\end{array}$ & $\begin{array}{l}\text { Grounded } \\
\text { Theory }\end{array}$ & $\begin{array}{l}\text { Means of } \\
\text { transport and } \\
\text { non- } \\
\text { monetary } \\
\text { incentives } \\
\text { help retain } \\
\text { community- } \\
\text { based } \\
\text { volunteers } \\
\text { and sustain. } \\
\text { Social } \\
\text { Support }\end{array}$ \\
\hline
\end{tabular}




\begin{tabular}{|c|c|c|c|c|c|c|}
\hline $\begin{array}{l}\text { Haski, L. D., Meijs, L. C. P. M., } \\
\text { Lockstone, B. L., Holmes, K., \& } \\
\text { Oppenheimer, M. (2018). Measuring } \\
\text { volunteerability and the capacity to } \\
\text { volunteer among non-volunteers: } \\
\text { Implications for social policy. Social } \\
\text { Policy \& Administration, 52(5), 1139- } \\
\text { 1167. https://doi.org/10.1111/spol.12342 }\end{array}$ & $\begin{array}{l}\text { Willingness } \\
\text {, capability, } \\
\text { and } \\
\text { availability } \\
\text { of } \\
\text { volunteers } \\
\text { are affected } \\
\text { by social } \\
\text { support. }\end{array}$ & $\begin{array}{l}\text { Design: Mixed } \\
\text { method } \\
\text { Tools Used: } \\
\text { questionnaire } \\
\text { Sample } \\
\text { Size: } 12 \text { focus } \\
\text { groups with a } \\
\text { total of } 1,700 \\
\text { responses } \\
\text { Evidence/Gra } \\
\text { de: Level I-B }\end{array}$ & $\begin{array}{l}\text { Understanding } \\
\text { the willingness, } \\
\text { capability, and } \\
\text { availability to } \\
\text { volunteer }\end{array}$ & $\begin{array}{l}\text { The government } \\
\text { should support } \\
\text { state and } \\
\text { national } \\
\text { volunteers and } \\
\text { allow volunteers } \\
\text { to volunteer } \\
\text { episodically, } \\
\text { online, and } \\
\text { through the } \\
\text { workplace. }\end{array}$ & None & $\begin{array}{l}\text { Opportunity } \\
\text { for social } \\
\text { policy to } \\
\text { allow for } \\
\text { volunteering. }\end{array}$ \\
\hline 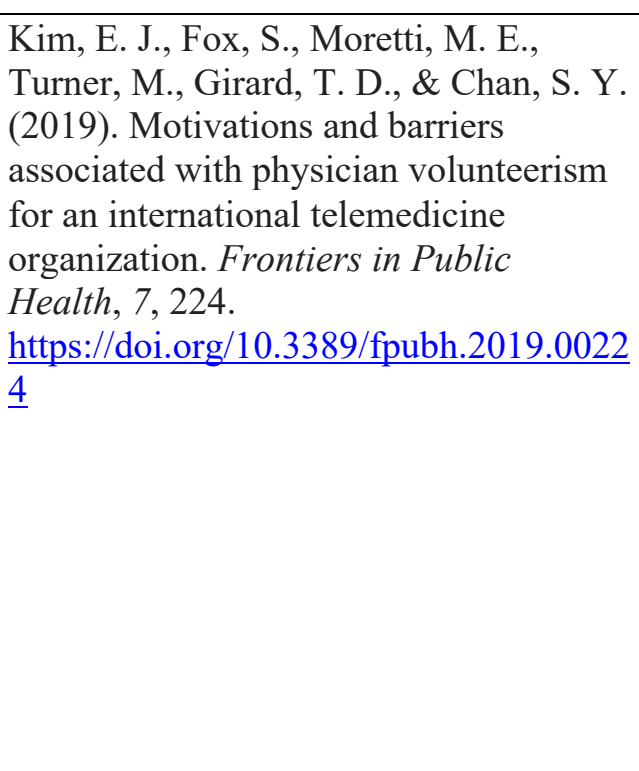 & $\begin{array}{l}\text { To identify } \\
\text { motivations } \\
\text { and barriers } \\
\text { that } \\
\text { contribute } \\
\text { to physician } \\
\text { volunteeris } \\
m \text { in } \\
\text { telemedicin } \\
\text { e. }\end{array}$ & $\begin{array}{l}\text { Design: } \\
\text { Descriptive } \\
\text { statistics, } \\
\text { qualitative } \\
\text { approach. } \\
\text { Tools: } \\
\text { surveys; VFI } \\
\text { framework } \\
\text { Sample Size: } \\
69 \text { active and } \\
25 \text { inactive } \\
\text { volunteers } \\
\text { with a } 74 \% \\
\text { response rate. } \\
\text { Evidence/Gra } \\
\text { de Level II-B }\end{array}$ & $\begin{array}{l}\text { A motivator is } \\
\text { the ability to } \\
\text { connect with the } \\
\text { patient. }\end{array}$ & $\begin{array}{l}\text { Predictors of } \\
\text { physician } \\
\text { volunteerism are } \\
\text { age and global } \\
\text { health } \\
\text { experience. }\end{array}$ & None & $\begin{array}{l}\text { Develop } \\
\text { effective } \\
\text { recruitment } \\
\text { and retention } \\
\text { strategies. }\end{array}$ \\
\hline $\begin{array}{l}\text { Mays, D. C., O'Neil, E. J., Jr, Mworozi, } \\
\text { E. A., Lough, B. J., Tabb, Z. J., } \\
\text { Whitlock, A. E., Mutimba, E. M., \& } \\
\text { Talib, Z. M. (2017). Supporting and }\end{array}$ & $\begin{array}{l}\text { To evaluate } \\
\text { specific } \\
\text { factors } \\
\text { associated }\end{array}$ & $\begin{array}{l}\text { Design: } \\
\text { Mixed method } \\
\text { with a survey } \\
\text { and semi- }\end{array}$ & $\begin{array}{l}\text { Desire for } \\
\text { support such as } \\
\text { transportation, } \\
\text { supplies, and }\end{array}$ & $\begin{array}{l}\text { Building } \\
\text { stronger } \\
\text { partnerships and } \\
\text { providing }\end{array}$ & None & $\begin{array}{l}10 \text {-year } \\
\text { longevity } \\
\text { was } \\
\text { positively }\end{array}$ \\
\hline
\end{tabular}




\begin{tabular}{|c|c|c|c|c|c|c|}
\hline $\begin{array}{l}\text { retaining village health teams: An } \\
\text { assessment of a community health } \\
\text { worker program in two Ugandan } \\
\text { districts. International Journal for } \\
\text { Equity in Health, 16(1), 129. } \\
\text { https://doi.org/10.1186/s12939-017- } \\
\underline{0619-6}\end{array}$ & $\begin{array}{l}\text { with long- } \\
\text { term } \\
\text { retention of } \\
\text { VHT. }\end{array}$ & $\begin{array}{l}\text { structured } \\
\text { interviews } \\
\text { Tools/ } \\
\text { Sample Size: } \\
\text { 134 VHT } \\
\text { Evidence/Gra } \\
\text { de Level I-A }\end{array}$ & $\begin{array}{l}\text { describe a lack of } \\
\text { respect and } \\
\text { support from } \\
\text { communities and } \\
\text { HVs. }\end{array}$ & $\begin{array}{l}\text { regular supplies } \\
\text { and } \\
\text { transportation. }\end{array}$ & & $\begin{array}{l}\text { associated } \\
\text { with stronger } \\
\text { partnerships } \\
\text { with local } \\
\text { health center } \\
\text { staff and ease } \\
\text { in-home } \\
\text { visits. } \\
\text { Logistics and } \\
\text { social } \\
\text { support }\end{array}$ \\
\hline $\begin{array}{l}\text { McGeehan, L., Takehara, M. A., \& } \\
\text { Daroszewski, E. (2017). Physicians' } \\
\text { perceptions of volunteer service at } \\
\text { safety-net clinics. The Permanente } \\
\text { Journal, 21, 16-003. } \\
\text { https://doi.org/10.7812/TPP/16-003 }\end{array}$ & $\begin{array}{l}\text { To } \\
\text { investigate } \\
\text { the } \\
\text { perceptions, } \\
\text { motivations } \\
\text {, functions, } \\
\text { and barriers } \\
\text { associated } \\
\text { with } \\
\text { physician } \\
\text { volunteerin } \\
\text { g. }\end{array}$ & $\begin{array}{l}\text { Design: } \\
\text { Mixed method } \\
\text { Tools: } \\
\text { surveys and } \\
\text { interviews, } \\
\text { Functions of } \\
\text { volunteering } \\
\text { from Clary et } \\
\text { al } \\
\text { Sample Size: } \\
31 \text { physicians } \\
\text { Evidence/Gra } \\
\text { de Level II-B }\end{array}$ & $\begin{array}{l}\text { Barriers were } \\
\text { time, } \\
\text { organizational, } \\
\text { and supply } \\
\text { issues. Most were } \\
\text { motivated by } \\
\text { humanitarian or } \\
\text { prosocial desires }\end{array}$ & $\begin{array}{l}\text { Appeal to the } \\
\text { volunteer's } \\
\text { sense of values, } \\
\text { faith, and } \\
\text { qualities of } \\
\text { volunteering. }\end{array}$ & None & $\begin{array}{l}\text { Appealing to } \\
\text { values and } \\
\text { faith and } \\
\text { burnout } \\
\text { prevention } \\
\text { qualities of } \\
\text { volunteering } \\
\text { are key to } \\
\text { recruitment } \\
\text { and } \\
\text { retention. }\end{array}$ \\
\hline $\begin{array}{l}\text { Meyer, M. A., Peek, L., Unnithan, N. P., } \\
\text { Coşkun, R., Tobin-Gurley, J., \& Hoffer, } \\
\text { K. H. (2016). Planning for diversity: } \\
\text { Evaluation of a volunteer disaster } \\
\text { response program. Journal of Cultural } \\
\text { Diversity, 23(3), 106-113. }\end{array}$ & $\begin{array}{l}\text { Reliance on } \\
\text { word of } \\
\text { mouth } \\
\text { recruiting } \\
\text { remains } \\
\text { commonpla } \\
\text { ce; } \\
\text { however, } \\
\end{array}$ & $\begin{array}{l}\text { Design: semi- } \\
\text { structured } \\
\text { phone } \\
\text { interviews } \\
\text { Tools Used: } \\
21 \text { open/closed } \\
\text { ended } \\
\text { questions; } 2 \\
\end{array}$ & $\begin{array}{l}\text { National } \\
\text { sometimes works } \\
\text { in isolation of } \\
\text { local volunteers. }\end{array}$ & $\begin{array}{l}\text { Planning for } \\
\text { diversity } \\
\text { requires clear } \\
\text { communication } \\
\text { throughout the } \\
\text { organization } \\
\text { especially } \\
\text { between }\end{array}$ & None & $\begin{array}{l}\text { Inform } \\
\text { volunteers of } \\
\text { lack of } \\
\text { diversity and } \\
\text { seek non- } \\
\text { traditional } \\
\text { ways to } \\
\text { recruit as } \\
\end{array}$ \\
\hline
\end{tabular}




\begin{tabular}{|c|c|c|c|c|c|c|}
\hline & $\begin{array}{l}\text { adding } \\
\text { diversity } \\
\text { recruitment } \\
\text { strategies } \\
\text { and goals } \\
\text { may } \\
\text { increase } \\
\text { recruitment. }\end{array}$ & $\begin{array}{l}\text { cycle coding } \\
\text { method } \\
\text { Sample Size: } \\
27 \text { individuals } \\
\text { Data } \\
\text { Analysis: } \\
\text { Review of } \\
\text { responses } \\
\text { Evidence/ } \\
\text { Grade Level } \\
\text { II-B }\end{array}$ & & $\begin{array}{l}\text { leadership at all } \\
\text { levels. }\end{array}$ & & $\begin{array}{l}\text { well as } \\
\text { involve } \\
\text { strategies } \\
\text { that improve } \\
\text { communicati } \\
\text { on with } \\
\text { leadership. }\end{array}$ \\
\hline $\begin{array}{l}\text { Mlotshwa, L., Harris, B., Schneider, H., } \\
\text { \& Moshabela, M. (2015). Exploring the } \\
\text { perceptions and experiences of } \\
\text { community health workers using role } \\
\text { identity theory. Global Health Action, } 8 \text {, } \\
28045 \text {. } \\
\text { https://doi.org/10.3402/gha.v8.28045 }\end{array}$ & $\begin{array}{l}\text { To explore } \\
\text { the } \\
\text { perceptions, } \\
\text { experiences } \\
\text {, and } \\
\text { identities of } \\
\text { CHWs as } \\
\text { they adopt a } \\
\text { CHW role } \\
\text { in rural } \\
\text { South } \\
\text { Africa } \\
\text { using a } \\
\text { 'role } \\
\text { identity } \\
\text { theory' }\end{array}$ & $\begin{array}{l}\text { Design: semi- } \\
\text { structured } \\
\text { interviews } \\
\text { Tools: } \\
\text { Interviews } \\
\text { Sample Size: } \\
18 \\
\text { Evidence/ } \\
\text { Grade Level } \\
\text { II-B }\end{array}$ & $\begin{array}{l}\text { A need exists for } \\
\text { instrumental/mat } \\
\text { erial support for } \\
\text { community } \\
\text { acceptance }\end{array}$ & $\begin{array}{l}\text { Allow the CHW } \\
\text { to teach, } \\
\text { promote health, } \\
\text { become health } \\
\text { systems } \\
\text { representative } \\
\text { supported with } \\
\text { resources }\end{array}$ & $\begin{array}{l}\text { Role } \\
\text { Identify } \\
\text { Theory }\end{array}$ & $\begin{array}{l}\text { Understandin } \\
\text { g role } \\
\text { identities and } \\
\text { how to } \\
\text { support them } \\
\text { for retention } \\
\text { strategies. }\end{array}$ \\
\hline $\begin{array}{l}\text { Moghaddam, H. R., Allahverdipour, H., } \\
\text { \& Matlabi, H. (2018). Successful } \\
\text { recruitment and retention strategies for } \\
\text { women health volunteers: viewpoints of } \\
\text { the volunteers' supervisors and relevant }\end{array}$ & $\begin{array}{l}\text { To find } \\
\text { successful } \\
\text { strategies to } \\
\text { overcome } \\
\text { barriers to }\end{array}$ & $\begin{array}{l}\text { Design: } \\
\text { Delphi } \\
\text { technique } \\
\text { Tools: } \\
\text { questionnaires }\end{array}$ & $\begin{array}{l}\text { Improve group } \\
\text { work, } \\
\text { implementing } \\
\text { motivation } \\
\text { tactics, allocating }\end{array}$ & $\begin{array}{l}\text { Utilize } \\
\text { incentives and } \\
\text { logistical } \\
\text { supplies such as } \\
\text { prizes and }\end{array}$ & None & $\begin{array}{l}\text { Community } \\
\text { mobilization, } \\
\text { incentive, } \\
\text { and logistical } \\
\text { supplies are }\end{array}$ \\
\hline
\end{tabular}




\begin{tabular}{|c|c|c|c|c|c|c|}
\hline $\begin{array}{l}\text { researchers. Journal of Multidisciplinary } \\
\text { Healthcare, 11, 621-634. } \\
\text { https://doi.org/10.2147/JMDH.S180544 }\end{array}$ & $\begin{array}{l}\text { recruitment } \\
\text { and } \\
\text { retention of } \\
\text { volunteers. }\end{array}$ & $\begin{array}{l}\text { Sample Size: } \\
\text { Unknown } \\
\text { Evidence/ } \\
\text { Grade Level/ } \\
\text { II-C }\end{array}$ & $\begin{array}{l}\text { resources, using } \\
\text { social networks, } \\
\text { and improving } \\
\text { collaboration are } \\
\text { some strategies } \\
\text { for retention. }\end{array}$ & $\begin{array}{l}\text { transportation } \\
\text { for volunteers to } \\
\text { retain CHWs. }\end{array}$ & & $\begin{array}{l}\text { mechanisms } \\
\text { for retention. }\end{array}$ \\
\hline $\begin{array}{l}\text { Ngilangwa, D. P., \& Mgomella, G. S. } \\
\text { (2018). Factors associated with retention } \\
\text { of community health workers in } \\
\text { maternal, newborn, and child health } \\
\text { programme in Simiyu Region, } \\
\text { Tanzania. African Journal of Primary } \\
\text { Health Care \& Family Medicine, 10(1), } \\
\text { e1-e8. } \\
\underline{\text { https://doi.org/10.4102/phcfm.v10i1.150 }} \\
\underline{6}\end{array}$ & $\begin{array}{l}\text { To } \\
\text { understand } \\
\text { factors } \\
\text { associated } \\
\text { with CHWs } \\
\text { recruitment } \\
\text { and } \\
\text { retention. }\end{array}$ & $\begin{array}{l}\text { Design: } \\
\text { Cross- } \\
\text { sectional study } \\
\text { Tools: semi- } \\
\text { structured } \\
\text { questionnaires } \\
\text { Sample Size: } \\
341 \text { CHW } \\
\text { Evidence/Gra } \\
\text { de Level/ II-A }\end{array}$ & $\begin{array}{l}\text { Motivation } \\
\text { factors were } \\
\text { aspiration to } \\
\text { serve, desire to } \\
\text { become a } \\
\text { qualified medical } \\
\text { practitioner. }\end{array}$ & $\begin{array}{l}\text { It is important to } \\
\text { understand the } \\
\text { motives for } \\
\text { volunteering. }\end{array}$ & None & $\begin{array}{l}\text { Retention of } \\
\text { CHWs } \\
\text { includes } \\
\text { financial and } \\
\text { non-financial } \\
\text { incentives. }\end{array}$ \\
\hline $\begin{array}{l}\text { Ngugi, A. K., Nyaga, L. W., Lakhani, } \\
\text { A., Agoi, F., Hanselman, M., Lugogo, } \\
\text { G., \& Mehta, K. M. (2018). Prevalence, } \\
\text { incidence, and predictors of volunteer } \\
\text { community health worker attrition in } \\
\text { Kwale County, Kenya. British Medical } \\
\text { Journal Global Health, 3(4), e000750. } \\
\text { https://doi.org/10.1136/bmjgh-2018- } \\
\underline{000750}\end{array}$ & $\begin{array}{l}\text { To measure } \\
\text { CHW } \\
\text { attrition and } \\
\text { its } \\
\text { predictors } \\
\text { in a rural } \\
\text { area. }\end{array}$ & $\begin{array}{l}\text { Design: case- } \\
\text { control study } \\
\text { and focus } \\
\text { group } \\
\text { discussions } \\
\text { Tools: } \\
\text { Poisson model } \\
\text { Sample Size: } \\
1005 \\
\text { Evidence/Gra } \\
\text { de Level II-B }\end{array}$ & $\begin{array}{l}\text { The incidence of } \\
\text { attrition was } \\
46.8 / 1000 \\
\text { person-years. } \\
\text { Lack of interest } \\
\text { in the peer } \\
\text { organization was } \\
\text { associated with } \\
\text { attrition. A heavy } \\
\text { caseload was } \\
\text { associated with } \\
\text { attrition. }\end{array}$ & $\begin{array}{l}\text { Ongoing training } \\
\text { and feedback } \\
\text { and peer support } \\
\text { are important in } \\
\text { retention. } \\
\text { Expectations } \\
\text { regarding the } \\
\text { roles and } \\
\text { benefits of } \\
\text { CHWs are to be } \\
\text { communicated } \\
\text { clearly. }\end{array}$ & $\begin{array}{l}\text { CHW } \\
\text { attrition } \\
\text { conceptual } \\
\text { framework. }\end{array}$ & $\begin{array}{l}\text { High } \\
\text { prevalence } \\
\text { and } \\
\text { incidence of } \\
\text { CHWs } \\
\text { attrition. }\end{array}$ \\
\hline $\begin{array}{l}\text { Nothwehr, F., \& Rohlman, D. (2019). } \\
\text { Employer-supported volunteerism in }\end{array}$ & $\begin{array}{l}\text { To } \\
\text { understand }\end{array}$ & $\begin{array}{l}\text { Design: } \\
\text { Descriptive }\end{array}$ & $\begin{array}{l}\text { Volunteerism has } \\
\text { been linked to }\end{array}$ & $\begin{array}{l}\text { Tailor to the } \\
\text { interest of }\end{array}$ & None & $\begin{array}{l}\text { Volunteerism } \\
\text { may lead to }\end{array}$ \\
\hline
\end{tabular}




\begin{tabular}{|c|c|c|c|c|c|c|}
\hline $\begin{array}{l}\text { rural worksites. Workplace Health \& } \\
\text { Safety, 67(10), 512-519. } \\
\text { https://doi.org/10.1177/2165079919862 } \\
\underline{295}\end{array}$ & $\begin{array}{l}\text { what small, } \\
\text { rural } \\
\text { worksites } \\
\text { are doing } \\
\text { about } \\
\text { volunteeris } \\
\text { m. }\end{array}$ & $\begin{array}{l}\text { statistics, } \\
\text { review, and } \\
\text { summary of } \\
\text { common } \\
\text { themes. } \\
\text { Tools: online } \\
\text { survey } \\
\text { Sample Size: } \\
38 \text { worksites } \\
\text { Evidence/Gra } \\
\text { de Level II-B }\end{array}$ & $\begin{array}{l}\text { improved quality } \\
\text { of life, reduced } \\
\text { morbidity, and } \\
\text { higher self-rated } \\
\text { activities. }\end{array}$ & $\begin{array}{l}\text { employees and } \\
\text { incorporate } \\
\text { health promotion } \\
\text { programs. }\end{array}$ & & $\begin{array}{l}\text { increased } \\
\text { employee } \\
\text { engagement, } \\
\text { improved } \\
\text { productivity } \\
\text { and } \\
\text { recruitment, } \\
\text { and } \\
\text { retention. }\end{array}$ \\
\hline $\begin{array}{l}\text { O'Donohue, W., Martin, A., \& Torugsa, } \\
\text { N. (Ann). (2015). Understanding } \\
\text { individual responses to failure by the } \\
\text { organisation to fulfill its obligations: } \\
\text { examining the influence of } \\
\text { psychological capital and psychological } \\
\text { contract type. Human Resource } \\
\text { Management Journal, 25(1), 131-147. } \\
\text { https://doi.org/10.1111/1748- } \\
\underline{8583.12055}\end{array}$ & $\begin{array}{l}\text { To test a } \\
\text { novel } \\
\text { theoretical } \\
\text { model } \\
\text { predicting } \\
\text { likely } \\
\text { worker } \\
\text { response in } \\
\text { an } \\
\text { emergency } \\
\text { services } \\
\text { organizatio } \\
\text { n using } \\
\text { volunteer } \\
\text { workers. }\end{array}$ & $\begin{array}{l}\text { Design: } \\
\text { Interviews } \\
\text { Tools Used: } \\
\text { PCS } \\
\text { Sample Size: } \\
592 \text { volunteers } \\
\text { Data } \\
\text { Analysis: } \\
\text { Review of } \\
\text { PC/PsyCap } \\
\text { responses } \\
\text { Evidence/Gra } \\
\text { de Level I-A }\end{array}$ & $\begin{array}{l}\text { PC: socio- } \\
\text { emotional } \\
\text { commitment. Psy } \\
\text { Cap includes } 4 \\
\text { positive } \\
\text { attributes: hope, } \\
\text { optimism, } \\
\text { resilience, self- } \\
\text { efficacy. }\end{array}$ & $\begin{array}{l}\text { Socio-emotional } \\
\text { commitment } \\
\text { leads to } \\
\text { fulfilling } \\
\text { organizational } \\
\text { obligations. }\end{array}$ & None & $\begin{array}{l}\text { Data } \\
\text { reinforces } \\
\text { the } \\
\text { importance } \\
\text { of sustaining } \\
\text { functional } \\
\text { relationships } \\
\text { between } \\
\text { leaders and } \\
\text { volunteers to } \\
\text { enhance } \\
\text { performance } \\
\text { and } \\
\text { productivity. }\end{array}$ \\
\hline $\begin{array}{l}\text { Omoto, A. M., \& Packard, C. D. (2016). } \\
\text { The power of connections: } \\
\text { Psychological sense of community as a } \\
\text { predictor of volunteerism. Journal of } \\
\text { Social Psychology, 156(3), 272-290. }\end{array}$ & $\begin{array}{l}\text { To support } \\
\text { the validity } \\
\text { and utility } \\
\text { of PSOC } \\
\text { for } \\
\text { understandi }\end{array}$ & $\begin{array}{l}\text { Design: } \\
\text { Questionnaires } \\
\text { in a group } \\
\text { survey then } \\
\text { follow up } \\
\text { questionnaire } \\
\end{array}$ & $\begin{array}{l}\text { Focus on } \\
\text { antecedents of } \\
\text { volunteerism: } \\
\text { PSOC is a } \\
\text { predictor of } \\
\text { volunteerism. }\end{array}$ & $\begin{array}{l}\text { Encourage } \\
\text { people to get } \\
\text { involved as } \\
\text { volunteers in } \\
\text { social issues and } \\
\text { causes. }\end{array}$ & $\begin{array}{l}\text { Volunteer } \\
\text { Process } \\
\text { Model; } 1^{\text {st }} \\
\text { study is } \\
\text { based on the } \\
\text { New }\end{array}$ & $\begin{array}{l}\text { Social } \\
\text { relationships } \\
\text { and } \\
\text { psychologica } \\
1 \text { connections } \\
\text { are potential }\end{array}$ \\
\hline
\end{tabular}




\begin{tabular}{|c|c|c|c|c|c|c|}
\hline & $\begin{array}{l}\text { ng } \\
\text { volunteeris } \\
\text { m. }\end{array}$ & $\begin{array}{l}\text { Tools: } \\
\text { Questionnaires } \\
\text { Sample Size/: } \\
140 \text { retirees } \\
\text { Analysis: } \\
\text { hierarchical } \\
\text { regression } \\
\text { analyses } \\
\text { Evidence/Gra } \\
\text { de Level } \\
\text { II-B }\end{array}$ & & $\begin{array}{l}\text { Connections to } \\
\text { other people are } \\
\text { crucial in } \\
\text { predicting } \\
\text { volunteerism } \\
\text { especially } \\
\text { PSOC. }\end{array}$ & $\begin{array}{l}\text { Ecological } \\
\text { paradigm } \\
\text { and the } 2^{\text {nd }} \\
\text { study is } \\
\text { based on the } \\
\text { Connectedn } \\
\text { ess to } \\
\text { nature. }\end{array}$ & $\begin{array}{l}\text { pathways to } \\
\text { volunteerism }\end{array}$ \\
\hline $\begin{array}{l}\text { Ortega Carpio, M. L., Martinez- } \\
\text { Cousinou, G., \& Morales-Fernández, E. } \\
\text { J. (2018). Transformative volunteerism: } \\
\text { An inventory of NGDO volunteers' } \\
\text { motivations. Human Service } \\
\text { Organizations: Management, } \\
\text { Leadership \& Governance, 42(1), 33- } \\
\text { 52. } \\
\underline{\text { https://doi.org/10.1080/23303131.2017. }} \\
\underline{1363103}\end{array}$ & $\begin{array}{l}\text { Designing } \\
\text { specific } \\
\text { volunteer } \\
\text { managemen } \\
\text { t programs } \\
\text { for } \\
\text { recruitment, } \\
\text { task } \\
\text { assignment, } \\
\text { and training } \\
\text { sustain } \\
\text { motivation. }\end{array}$ & $\begin{array}{l}\text { Design: } \\
\text { Structured } \\
\text { interviews } \\
\text { Tools Used: } \\
\text { closed-ended } \\
\text { questionnaire } \\
\text { Sample Size: } \\
376 \text { volunteers } \\
\text { Data } \\
\text { Analysis: } \\
\text { Principal } \\
\text { component } \\
\text { analysis } \\
\text { Evidence/ } \\
\text { Grade: Level } \\
\text { IA }\end{array}$ & $\begin{array}{l}\text { Volunteerism } \\
\text { favors our vision } \\
\text { of the world and } \\
\text { promotes } \\
\text { proposals for } \\
\text { action and social } \\
\text { transformation. }\end{array}$ & $\begin{array}{l}\text { Volunteer as an } \\
\text { agent of change } \\
\text { or } \\
\text { transformative } \\
\text { volunteerism. }\end{array}$ & None & $\begin{array}{l}\text { Assignment } \\
\text { of tasks } \\
\text { motivates } \\
\text { volunteers } \\
\text { and } \\
\text { encourages } \\
\text { change } \\
\text { through } \\
\text { social } \\
\text { transformatio } \\
\text { n. }\end{array}$ \\
\hline $\begin{array}{l}\text { Salmani, I., Seyedin, H., Ardalan, A., \& } \\
\text { Farajkhoda, T. (2019). Conceptual } \\
\text { model of managing health care } \\
\text { volunteers in disasters: A mixed method } \\
\text { study. Bio Med Central Health Services }\end{array}$ & $\begin{array}{l}\text { Volunteer } \\
\text { preparednes } \\
\text { s plans that } \\
\text { are } \\
\text { integrated }\end{array}$ & $\begin{array}{l}\text { Design: Mixed } \\
\text { method } \\
\text { Tools Used: }\end{array}$ & $\begin{array}{l}\text { Prioritize } \\
\text { retention and } \\
\text { motivation } \\
\text { through plans for } \\
\text { addressing }\end{array}$ & $\begin{array}{l}\text { Utilize the } \\
\text { preparedness } \\
\text { phase to prepare } \\
\text { HVs and utilize } \\
\text { the response }\end{array}$ & None & $\begin{array}{l}\text { Management } \\
\text { of volunteers } \\
\text { regarding } \\
\text { preparedness } \\
\text {, response, }\end{array}$ \\
\hline
\end{tabular}




\begin{tabular}{|c|c|c|c|c|c|c|}
\hline $\begin{array}{l}\text { Research, 19(1), } 241 . \\
\text { https://doi.org/10.1186/s12913-019- } \\
\underline{4073-6}\end{array}$ & $\begin{array}{l}\text { into the risk } \\
\text { reduction } \\
\text { programs of } \\
\text { the health } \\
\text { system } \\
\text { prove to } \\
\text { work better. }\end{array}$ & $\begin{array}{l}\text { Delphi; semi- } \\
\text { structured } \\
\text { interviews } \\
\text { Sample Size: } \\
22 \text { health } \\
\text { professionals. } \\
\text { Theoretical } \\
\text { sampling } \\
\text { Data } \\
\text { Analysis: a } \\
\text { framework } \\
\text { analysis } \\
\text { Evidence/Gra } \\
\text { de: Level I-A }\end{array}$ & $\begin{array}{l}\text { physical and } \\
\text { mental health } \\
\text { follow up after a } \\
\text { mission. }\end{array}$ & $\begin{array}{l}\text { phase to assign } \\
\text { them } \\
\text { appropriately; } \\
\text { finally, during } \\
\text { the post- } \\
\text { response phase } \\
\text { follow up } \\
\text { physical and } \\
\text { mental health } \\
\text { status. }\end{array}$ & & $\begin{array}{l}\text { and follow- } \\
\text { up may } \\
\text { impact } \\
\text { retention. }\end{array}$ \\
\hline $\begin{array}{l}\text { Sarti, A. J., Sutherland, S., Landriault, } \\
\text { A., DesRosier, K., Brien, S., \& Cardinal, } \\
\text { P. (2017). Exploring the components of } \\
\text { physician volunteer engagement: A } \\
\text { qualitative investigation of a national } \\
\text { Canadian simulation-based training } \\
\text { programme. British Medical Journal } \\
\text { Open, 7(6), e014303. } \\
\underline{\text { https://doi.org/10.1136/bmjopen-2016- }} \underline{\underline{014303}}\end{array}$ & $\begin{array}{l}\text { To present a } \\
\text { conceptual } \\
\text { framework } \\
\text { for the } \\
\text { exploration } \\
\text { of volunteer } \\
\text { engagement } \\
\text { and } \\
\text { influencing } \\
\text { for } \\
\text { physician } \\
\text { volunteers. }\end{array}$ & $\begin{array}{l}\text { Design: } \\
\text { qualitative } \\
\text { analysis; semi- } \\
\text { structured } \\
\text { interviews and } \\
\text { construction of } \\
\text { a conceptual } \\
\text { framework } \\
\text { Tools/ } \\
\text { Sample Size: } \\
\text { 30 } \\
\text { Evidence/Gra } \\
\text { de Level II-B }\end{array}$ & $\begin{array}{l}\text { Framework } \\
\text { elements include } \\
\text { synergism of } \\
\text { emotional, } \\
\text { cognitive, and } \\
\text { reciprocal } \\
\text { engagement. }\end{array}$ & $\begin{array}{l}\text { Retention is } \\
\text { associated with } \\
\text { leadership and } \\
\text { career paths, } \\
\text { intrinsic, } \\
\text { keeping current, } \\
\text { academic } \\
\text { currency, } \\
\text { personal } \\
\text { recognition, and } \\
\text { CV }\end{array}$ & $\begin{array}{l}\text { Fredericks } \\
\text { et al., } \\
\text { Theory of } \\
\text { engagement }\end{array}$ & $\begin{array}{l}\text { Provides a } \\
\text { preliminary } \\
\text { framework } \\
\text { for physician } \\
\text { volunteer } \\
\text { engagement. }\end{array}$ \\
\hline $\begin{array}{l}\text { Smith, S. L., \& Grove, C. J. (2017). } \\
\text { Bittersweet and paradoxical. Nonprofit } \\
\text { Management \& Leadership, 27(3), 353- } \\
\text { 369. https://doi.org/10.1002/nml.21250 }\end{array}$ & $\begin{array}{l}\text { Positive } \\
\text { managemen } \\
\mathrm{t} \text { practices } \\
\text { lead to } \\
\text { more }\end{array}$ & $\begin{array}{l}\text { Design: Semi- } \\
\text { structured } \\
\text { interview } \\
\text { protocol }\end{array}$ & $\begin{array}{l}\text { How managers } \\
\text { practice shape } \\
\text { satisfaction and } \\
\text { fatigue among } \\
\text { skilled long-term } \\
\text { volunteers }\end{array}$ & $\begin{array}{l}\text { Volunteer } \\
\text { management } \\
\text { practices affect } \\
\text { satisfaction and } \\
\text { retention. } \\
\text { Perception of }\end{array}$ & $\begin{array}{l}\text { Herzberg's } \\
(1968) \text { two- } \\
\text { factor } \\
\text { theory }\end{array}$ & $\begin{array}{l}\text { Volunteer } \\
\text { management } \\
\text { practices } \\
\text { regarding } \\
\text { forms, } \\
\text { frequency, }\end{array}$ \\
\hline
\end{tabular}




\begin{tabular}{|c|c|c|c|c|c|c|}
\hline & $\begin{array}{l}\text { satisfied } \\
\text { volunteers }\end{array}$ & $\begin{array}{l}\text { Tools Used: } \\
\text { open-ended } \\
\text { questions } \\
\text { Sample Size: } \\
16 \\
\text { Data } \\
\text { Analysis: } \\
\text { MANOVA, } \\
\text { ANOVA } \\
\text { Evidence/Gra } \\
\text { de II-B }\end{array}$ & & $\begin{array}{l}\text { supportive } \\
\text { Worker- } \\
\text { organization } \\
\text { relationship. }\end{array}$ & & $\begin{array}{l}\text { the timing of } \\
\text { communicati } \\
\text { on, } \\
\text { recognition, } \\
\text { and support } \\
\text { services } \\
\text { affect } \\
\text { satisfaction } \\
\text { and } \\
\text { retention. }\end{array}$ \\
\hline $\begin{array}{l}\text { Vareilles, G., Marchal, B., Kane, S., } \\
\text { Petrič, T., Pictet, G., \& Pommier, J. } \\
\text { (2015). Understanding the motivation } \\
\text { and performance of community health } \\
\text { volunteers involved in the delivery of } \\
\text { health programmes in Kampala, } \\
\text { Uganda: A realist evaluation. British } \\
\text { Medical Journal Open, 5(11), e008614. } \\
\underline{\text { https://doi.org/10.1136/bmjopen-2015- }} \\
\underline{008614}\end{array}$ & $\begin{array}{l}\text { To } \\
\text { understand } \\
\text { how, why, } \\
\text { and under } \\
\text { what } \\
\text { circumstanc } \\
\text { es a Red } \\
\text { Cross } \\
\text { capacity } \\
\text { intervention } \\
\text { influencing } \\
\text { the } \\
\text { motivation } \\
\text { and } \\
\text { performanc } \\
\text { e of } \\
\text { volunteers. }\end{array}$ & $\begin{array}{l}\text { Design: case } \\
\text { study design } \\
\text { and realist } \\
\text { evaluation. } \\
\text { Constant } \\
\text { comparative } \\
\text { method } \\
\text { Tools: } \\
\text { interviews } \\
\text { Sample Size: } \\
1 \text { manger and } \\
15 \text { volunteers } \\
\text { Evidence/Gra } \\
\text { de Level II-C }\end{array}$ & $\begin{array}{l}\text { Recognition of } \\
\text { work and } \\
\text { responsiveness to } \\
\text { community needs } \\
\text { are Findings that } \\
\text { inform } \\
\text { management of } \\
\text { CHW and all } \\
\text { other volunteers }\end{array}$ & $\begin{array}{l}\text { Cater to the } \\
\text { motivational } \\
\text { states and } \\
\text { changing needs } \\
\text { of the volunteers } \\
\text { leads to better } \\
\text { performance. }\end{array}$ & $\begin{array}{l}\text { Realist } \\
\text { evaluative } \\
\text { theory- } \\
\text { driven } \\
\text { inquiry }\end{array}$ & $\begin{array}{l}\text { Feelings of } \\
\text { autonomy, } \\
\text { competence, } \\
\text { and } \\
\text { connectednes } \\
\text { s come from } \\
\text { supportive } \\
\text { supervision }\end{array}$ \\
\hline $\begin{array}{l}\text { Wilson, J., \& Son, J. (2018). The } \\
\text { connection between neighboring and } \\
\text { volunteering. City \& Community, 17(3), } \\
720-736 . \\
\text { https://doi.org/10.1111/cico.12324 }\end{array}$ & $\begin{array}{l}\text { Higher } \\
\text { neighboring } \\
\text { relationship } \\
\text { s lead to }\end{array}$ & $\begin{array}{l}\text { Design: } \\
\text { Interviews } \\
\text { Tools Used: } \\
\text { MIDUS }\end{array}$ & $\begin{array}{l}\text { Regarding } \\
\text { volunteers, } \\
\text { behaviors are } \\
\text { more important } \\
\text { than attitudes. }\end{array}$ & $\begin{array}{l}\text { Social media can } \\
\text { be used to } \\
\text { enhance } \\
\text { neighboring } \\
\text { relationships to }\end{array}$ & $\begin{array}{l}\text { Sociological } \\
\text { Theory }\end{array}$ & $\begin{array}{l}\text { The } \\
\text { influence of } \\
\text { social } \\
\text { connections } \\
\text { might be }\end{array}$ \\
\hline
\end{tabular}




\begin{tabular}{|l|l|l|l|l|l|}
\hline & $\begin{array}{l}\text { volunteerin } \\
\text { g. }\end{array}$ & $\begin{array}{l}\text { Sample Size: } \\
3,487 \\
\text { respondents } \\
\text { Data } \\
\text { Analysis: } \\
\text { Review of } \\
\text { responses } \\
\text { Evidence/Gra } \\
\text { de: Level I-A }\end{array}$ & & & engage in \\
volunteering. & & \\
if socially \\
integrated.
\end{tabular}

Legend: Community-based Health Worker (CBHW); Village health teams (VHT); Psychological contract (PC) and Psychological capital

(PsyCap); Community health workers (CHW); Women Health Volunteers (WHV); Curriculum vitae (CV); Psychological sense of community (PSOC); Volunteer Functions Inventory (VFI). 


\section{Appendix E}

\section{Summary of Themes}

\begin{tabular}{|c|c|c|c|c|c|c|c|}
\hline Themes & $\begin{array}{l}\text { Afari- } \\
\text { Asiedu, } \\
\text { S., } \\
\text { Asante, } \\
\text { K. P., } \\
\text { Senah, } \\
\text { K., } \\
\text { Abdulai, } \\
\text { M. A., } \\
\text { Afranie, } \\
\text { S., } \\
\text { Mahama, } \\
\text { E., } \\
\text { Anane, E. } \\
\text { A., } \\
\text { Abukari, } \\
\text { M., } \\
\text { Darko, } \\
\text { M. L., } \\
\text { Febir, L. } \\
\text { G., \& } \\
\text { Owusu- } \\
\text { Agyei, S. } \\
\text { (2018). } \\
\text { Volunteer } \\
\text { ing for } \\
\text { health } \\
\text { services } \\
\text { in the } \\
\text { middle } \\
\text { part of } \\
\text { Ghana: In }\end{array}$ & $\begin{array}{l}\text { Albuqu } \\
\text { erque, } \\
\text { S., } \\
\text { Eriksso } \\
\text { n, A., } \\
\text { \& } \\
\text { Alvess } \\
\text { on, H. } \\
\text { M. } \\
\text { (2018). } \\
\text { The } \\
\text { rite of } \\
\text { passag } \\
\text { e of } \\
\text { becomi } \\
\text { ng a } \\
\text { humani } \\
\text { tarian } \\
\text { health } \\
\text { worker } \\
\text { Experi } \\
\text { ences } \\
\text { of } \\
\text { retenti } \\
\text { on in } \\
\text { Swede } \\
\text { n. } \\
\text { Global } \\
\text { Health } \\
\text { Action, } \\
11(1),\end{array}$ & $\begin{array}{l}\text { Chatio, S., \& } \\
\text { Akweongo, P. } \\
\text { (2017). } \\
\text { Retention and } \\
\text { sustainability of } \\
\text { community- } \\
\text { based health } \\
\text { volunteers' } \\
\text { activities: A } \\
\text { qualitative study } \\
\text { in rural Northern } \\
\text { Ghana. PloS } \\
\text { One, 12(3), } \\
\text { e0174002. } \\
\text { https://doi.org/10 } \\
.1371 / \text { journal.po } \\
\text { ne.0174002 }\end{array}$ & $\begin{array}{l}\text { Mlotshwa, L., } \\
\text { Harris, B., } \\
\text { Schneider, H., \& } \\
\text { Moshabela, M. } \\
\text { (2015). Exploring } \\
\text { the perceptions } \\
\text { and experiences of } \\
\text { community health } \\
\text { workers using role } \\
\text { identity } \\
\text { theory. Global } \\
\text { Health Action, } 8, \\
28045 \text {. } \\
\underline{\text { https://doi.org/10. }} \\
\underline{3402 / \text { gha.v8.2804 }} \\
\underline{5}\end{array}$ & $\begin{array}{l}\text { Ngilangwa, D. } \\
\text { P., \& } \\
\text { Mgomella, G. } \\
\text { S. (2018). } \\
\text { Factors } \\
\text { associated with } \\
\text { retention of } \\
\text { community } \\
\text { health workers } \\
\text { in maternal, } \\
\text { newborn, and } \\
\text { child health } \\
\text { programme in } \\
\text { Simiyu Region, } \\
\text { Tanzania. Afric } \\
\text { an Journal of } \\
\text { Primary Health } \\
\text { Care \& Family } \\
\text { Medicine, 10(1) } \\
\text {, e1-e8. } \\
\text { https://doi.org/ } \\
\text { 10.4102/phcfm. } \\
\text { v10i1.1506 }\end{array}$ & $\begin{array}{l}\text { Ngugi, A. K., } \\
\text { Nyaga, L. W., } \\
\text { Lakhani, A., } \\
\text { Agoi, F., } \\
\text { Hanselman, M., } \\
\text { Lugogo, G., \& } \\
\text { Mehta, K. M. } \\
\text { (2018). } \\
\text { Prevalence, } \\
\text { incidence, and } \\
\text { predictors of } \\
\text { volunteer } \\
\text { community } \\
\text { health worker } \\
\text { attrition in } \\
\text { Kwale County, } \\
\text { Kenya. British } \\
\text { Medical Journal } \\
\text { Global } \\
\text { Health, 3(4), } \\
\text { e000750. } \\
\text { https://doi.org/1 } \\
\text { 0.1136/bmjgh- } \\
\text { 2018-000750 }\end{array}$ & $\begin{array}{l}\text { Salmani, I., } \\
\text { Seyedin, H., } \\
\text { Ardalan, A., \& } \\
\text { Farajkhoda, T. } \\
\text { (2019). } \\
\text { Conceptual } \\
\text { model of } \\
\text { managing health } \\
\text { care volunteers } \\
\text { in disasters: A } \\
\text { mixed method } \\
\text { study. Bio Med } \\
\text { Central Health } \\
\text { Services } \\
\text { Research, 19(1), } \\
\text { 241. } \\
\text { https://doi.org/1 } \\
\text { 0.1186/s12913- } \\
\text { 019-4073-6 }\end{array}$ \\
\hline
\end{tabular}




\begin{tabular}{|c|c|c|c|c|c|c|c|}
\hline & $\begin{array}{l}\text { whose } \\
\text { interest? } \\
\text { Internatio } \\
\text { nal } \\
\text { journal of } \\
\text { health } \\
\text { policy } \\
\text { and } \\
\text { managem } \\
\text { ent, } 7(9), \\
836-846 . \\
\text { https://doi } \\
\underline{\text { org/10.15 }} \\
\underline{171 / \mathrm{ijhpm}} \\
.2018 .38\end{array}$ & $\begin{array}{l}1 . \\
\text { https:// } \\
\underline{\text { doi.org }} \\
\frac{/ 10.10}{\frac{80 / 165}{49716 .}} \\
\underline{2017.1} \\
\underline{417522}\end{array}$ & & & & & \\
\hline Mentoring & $\begin{array}{l}\text { Recognitio } \\
\text { n by } \\
\text { Communit } \\
\text { y }\end{array}$ & $\begin{array}{l}\text { Support } \\
\text { system }\end{array}$ & Recognition & $\begin{array}{l}\text { Community } \\
\text { acceptance }\end{array}$ & $\begin{array}{l}\text { Supportive } \\
\text { supervision }\end{array}$ & $\begin{array}{l}\text { Supportive peer } \\
\text { Supervision \& } \\
\text { feedback }\end{array}$ & Supervision \\
\hline Education and Training & $\begin{array}{l}\text { Receive } \\
\text { and } \\
\text { provide } \\
\text { training }\end{array}$ & $\begin{array}{l}\text { Supervi } \\
\text { sion } \\
\text { and } \\
\text { mentori } \\
\text { ng }\end{array}$ & $\begin{array}{l}\text { Learning and } \\
\text { awareness }\end{array}$ & $\begin{array}{l}\text { Role identity learn } \\
\text { and teach }\end{array}$ & $\begin{array}{l}\text { Refresher } \\
\text { training and } \\
\text { further training }\end{array}$ & $\begin{array}{l}\text { Ongoing training } \\
\text { and acquisition of } \\
\text { knowledge }\end{array}$ & Preparedness \\
\hline Social Support & $\begin{array}{l}\text { Social } \\
\text { prestige }\end{array}$ & $\begin{array}{l}\text { Rite of } \\
\text { passage }\end{array}$ & $\begin{array}{l}\text { Sense of } \\
\text { responsibility } \\
\text { Prestige }\end{array}$ & $\begin{array}{l}\text { Become } \\
\text { representatives }\end{array}$ & $\begin{array}{l}\text { Importance to } \\
\text { the community }\end{array}$ & $\begin{array}{l}\text { Clear expectations } \\
\text { Sense of } \\
\text { accomplishment }\end{array}$ & $\begin{array}{l}\text { Social fun and } \\
\text { respect at all } \\
\text { stages }\end{array}$ \\
\hline
\end{tabular}

Legend: Non-government Organizations (NGO) 


\section{Appendix F}

\section{Strengths, Weakness, Opportunities, and Threats Analysis}

\begin{tabular}{|c|c|c|}
\hline & Internal Factors & External Factors \\
\hline & Strengths & Opportunities \\
\hline o & A strong mission, vision, core values, and & - Increase collaboration with local \\
\hline & pillars with a guiding philosophy. & healthcare organizations during disasters. \\
\hline 0 & History of volunteerism in existence since & - Improve coordination with colleges for \\
\hline & 1881. & support before disaster relief efforts. \\
\hline ○ & Reputation and respect internationally and & \\
\hline & known for responding to disasters & \\
\hline & globally. & \\
\hline 0 & Technology, resources, and leadership & \\
\hline & support for training. & \\
\hline & Weakness & Threats \\
\hline 0 & Reduced healthcare volunteer & o Exhausting volunteer resources caused by \\
\hline & participation & longstanding disaster relief missions. \\
\hline 0 & Lack of established structured mentoring, & ○ Multiple disasters and humanitarian needs \\
\hline & education, and training. & affecting the area locally. \\
\hline o & Lack of a retention program. & \\
\hline
\end{tabular}




\section{Appendix G}

\section{EBP Project Schedule}

\begin{tabular}{|l|l|l|}
\hline \multicolumn{1}{|c|}{ Action } & \multicolumn{1}{|c|}{ Schedule } & Responsibility \\
\hline 1. USAHS and IVO approve EBP Project & June 14-20, 2020 & PM \\
\hline 2. Discuss EBP implementation and projected budget & June 21-27, 2020 (W1) & PM, RDHSL \\
\hline 3. Baseline data analysis to stakeholders & June 21-27, 2020 (W1) & PM, RDHSL \\
\hline 4. Introduction of planned EBP project & June 21-27, 2020 (W1) & PM \\
\hline 5. Created and administered VFI pre-implementation survey & June 28-July 4, 2020 (W2) & PM, RDHSL \\
\hline 6. Educated mentors & June 28-July 4, 2020 (W2) & PM \\
\hline 7. Implementation of Healthcare Volunteer Retention Program & July 4-September 12, 2020 (W3-12) & PM \\
\hline 8. VFI pre-implementation survey analysis to stakeholders & August 9-15, 2020 (W8) & PM \\
\hline 9. Administered VFI post-implementation survey & September 6-12, 2020 (W12) & PM, Statistician \\
\hline 10. VFI post-implementation survey analysis to stakeholders & September 13-19, 2020 & PM \\
\hline 11. Outcome data analysis with Statistician & September 13-19, 2020 & September 20-26, 2020 \\
\hline 12. EBP project evaluation presented results to stakeholders & & \\
\hline
\end{tabular}

Legend: University of St. Augustine Health Sciences (USAHS); Interdisciplinary Volunteer Organization (IVO); Program Manager (PM);

Evidence-based Practice (EBP); Week (W); Regional Disaster Health Services Lead (RDHSL); Volunteer Functions Inventory (VFI); 


\section{Appendix H}

Measures for Healthcare Volunteer Retention Program (HVRP)

\begin{tabular}{|c|c|c|c|c|}
\hline Measure & Actions & Benchmark & Goal & Data Type \\
\hline $\begin{array}{l}\text { Outcome } \\
\text { Measure }\end{array}$ & $\begin{array}{l}\text { Retention Rate per } \mathbf{1 0 0} \text { - } \\
\text { Healthcare Worker Retention } \\
\text { Rate Percentage. The numerator } \\
\text { is the number of healthcare } \\
\text { worker volunteers who stayed for } \\
\text { a whole time divided by the } \\
\text { number of healthcare worker } \\
\text { volunteers at the start of a period } \\
\text { and multiply by } 100 \text {. }\end{array}$ & $5 \%$ & $\geq 50 \%$ & Continuous data \\
\hline $\begin{array}{l}\text { Outcome } \\
\text { Measure }\end{array}$ & $\begin{array}{l}\text { Percent of Healthcare } \\
\text { Volunteer Intent to stay. }\end{array}$ & $5 \%$ & $\geq 50 \%$ & $\begin{array}{l}\text { Continuous data } \\
\mathrm{x} 2 \text { paired }\end{array}$ \\
\hline $\begin{array}{l}\text { Outcome } \\
\text { Measure }\end{array}$ & $\begin{array}{l}\text { Percent of Healthcare } \\
\text { Volunteer satisfaction. }\end{array}$ & $5 \%$ & $\geq 50 \%$ & $\begin{array}{l}\text { Continuous data } \\
\mathrm{x} 2 \text { paired }\end{array}$ \\
\hline $\begin{array}{l}\text { Process } \\
\text { Measure }\end{array}$ & $\begin{array}{l}\text { Percent of Mentor education } \\
\text { and training. The numerator is } \\
\text { the actual number of mentors } \\
\text { who completed HVRP training } \\
\text { and the denominator is the total } \\
\text { number of Mentors who have } \\
\text { implemented the HVRP }\end{array}$ & $50 \%$ & $\geq 75 \%$ & $\begin{array}{l}\text { Continuous data } \\
\mathrm{x}^{2}\end{array}$ \\
\hline $\begin{array}{l}\text { Balance } \\
\text { Measure }\end{array}$ & $\begin{array}{l}\text { Percent of volunteers satisfied } \\
\text { with the HVRP }\end{array}$ & $5 \%$ & $\geq 50 \%$ & Continuous data \\
\hline $\begin{array}{l}\text { Financial } \\
\text { Measure }\end{array}$ & $\begin{array}{l}\text { Cost of Training. The number of } \\
\text { volunteers who responded to the } \\
\text { surveys multiplied by a } \$ 5 \\
\text { incentive. }\end{array}$ & & & \\
\hline $\begin{array}{l}\text { Sustainability } \\
\text { Measure }\end{array}$ & $\begin{array}{l}\text { Percent of Volunteers enrolled } \\
\text { in the HVRP. The numerator is } \\
\text { the total mentees enrolled and the } \\
\text { denominator is the total number } \\
\text { of volunteers. }\end{array}$ & $75 \%$ & $\geq 75 \%$ & $\begin{array}{l}\text { Continuous data } \\
\mathrm{x}^{2}\end{array}$ \\
\hline
\end{tabular}

